\title{
Summary of Hydrologic
}

Conditions of the

\section{Louisville Area}

Kentucky

GEOLOGICAL SURVEY WATER-SUPPLY PAPER 1819-C

Prepared in cooperation with the Commonwealth of Kentucky and the University of Kentucky, Kentucky Geological Survey

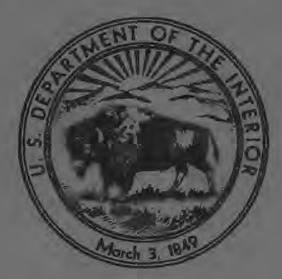




\section{Summary of Hydrologic}

Conditions of the

\section{Louisville Area}

\section{Kentucky}

By EDWIN A. BELL

CONTRIBUTIONS TO THE HYDROLOGY OF THE UNITED STATES

GEOLOGICAL SURVEY WATER-SUPPLY PAPER 1819-C

Prepared in cooperation with the Commonwealth of $K$ entucky and the University of $K$ entucky, Kentucky Geological Survey

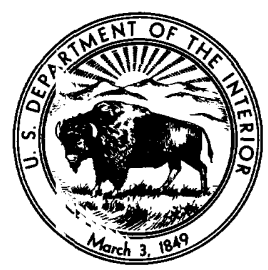




\title{
UNITED STATES DEPARTMENT OF THE INTERIOR
}

STEWART L. UDALL, Secretary

\author{
GEOLOGIGAL SURVEY
}

William T. Pecora, Director

For sale by the Superintendent of Documents, U.S. Government Printing Office Washington, D.C. 20402 - Price $\$ 1.50$ 


\section{CONTENTS}

Page

Abstract__._-

Purpose and scope.

Results of investigations

Cooperation and acknowledgments

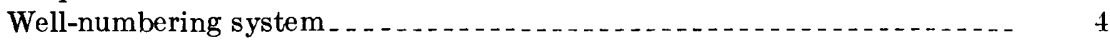

Description of the area.

The hydrologic system

Geologic framework

Hydrology _..._._.

Relation of hydrologic system to water utilization

The available water supply _.......... 9

The Ohio River _... 10

Discharge . .

Chemical quality and pollution

Small streams _...

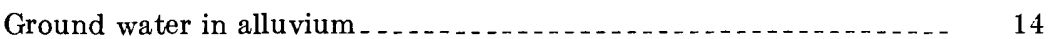

Natural recharge to the alluvium _...

Induced recharge to the alluvium

Natural discharge from the alluvium.

Chemical quality and temperature

Ground water in bedrock. 18

Water-supply development_. 19

Utilization of water.

Effects of water development. 20

Conditions affecting optimum development of water resources__._.

Distribution of available water supplies_ _ _

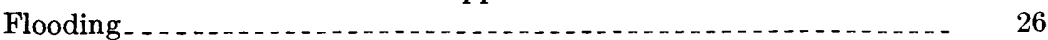

Droughts_._._._._.

Chemical quality and poilution

Drainage................ 32

Conclusions._... 33

Selected references..._. 


\section{ILLUSTRATIONS}

[Plates are in pocket]

Plate 1. Block diagram showing physiographic and geologic features that control the movement of natural waters.

2-5. Maps showing-

2. Thickness of saturated sand and gravel beneath the flood plain, December 1962, and degree of hydraulic connection between the river and aquifer.

3. Water-level contours beneath the flood plain of the Ohio River, December 1962.

4. The chemical character of ground water beneath the flood plain.

5. Quantity and quality of ground water.

6. Graphs showing precipitation, pumpage, and water levels in selected wells.

Figure 1. Map of Kentucky showing area covered by this repor ${ }^{+}$

Page

2. Diagram showing hydrologic cycle in the Louisville area,

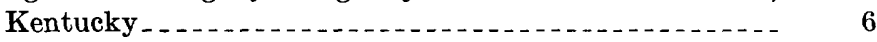

3-5. Graphs showing-

3. Departure from normal precipitation at U.S. Weather

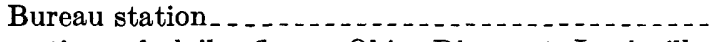

4. Duration of daily flows, Ohio River at Louisville, 1928-62 _. . . . . .

5. Low-flow frequencies, Ohio River at Louisville, 1928-62 . . . . . . .

6. Map showing the distribution of ground-water pumping, 1962

1962

\section{TABLES}

TABLE 1. Breakdown of references according to topic.......

2. Effects of water development on hydrologic conditions in the Louisville area 


\title{
CONTRIBUTIONS TO THE HYDROLOGY OF THE UNITED STATES
}

\section{SUMMARY OF HYDROLOGIC CONDITIONS OF THE LOUISVILLE AREA, KENTUGKY}

\author{
By Edwin A. Bell
}

\begin{abstract}
Water problems and their solution have been associated with the gr?wth and development of the Louisville area for more than a century. Many hydrologic data that aided water users in the past can be applied to present water problems and will be helpful for solving many similar problems in the future. Most of the water problems of Louisville, a water-rich area, concern management and are associated with the distribtuion of supplies, the quality of water, drainage, and waste disposal.

The local hydrologic system at Louisville is dominated by the Ohio Piver and the glacial-outwash deposits beneath its flood plain. The water-bearing limestones in the uplands are secondary sources of water. The average flow of the Ohio River at Louisville, 73 billion gallons per day, and the potential arailability of 370 million gallons per day of ground water suitable for industrial cooling purposes minimize the chance of acute water shortage in the area. Under current development, use of water averages about 211 million gallons per day, excluding about 392 million gallons of Ohio River water circulated daily through steampower plants and returned directly to the river. Optimum use ard control of the water resources will be dependent on solving several water problems.

The principal sources of water are in the Ohio River bottom land. whereas the new and potential centers of use are in the uplands. Either water must be piped to these new centers from the present sources or new suprlies must be developed. Available data on streamflow and ground water are adequate to plan for the development of small local supplies.

Since the completion of floodwalls and levees in 1953, widespread damage from flooding is a thing of the past in the Louisville area. Some local flooding of unprotected areas and of lowlands along tributary streams still takes place. The analyses of streamflow data are useful in planning for protection of these areas, but additional streamflow records and flood-area mapping are needed to best solve the problem. Droughts are a problem only to users of small water supplies in the uplands, where additional water either can be imrorted or developed locally.

Pollution and undesirable chemical quality of water for some uses are the most serious drawbacks to the optimum development of the water resources in Louisville and Jefferson County. Available chemical analyses of ground water
\end{abstract}


are useful for determining its suitability for various uses, but additional data are needed to guide management decisions. Sources of contamination should be inventoried and water samples analyzed periodically to monitor changes in quality.

\section{PURPOSE AND SCOPE}

This report describes the hydrologic system and its operation, identifies Louisville's water problems, and shows how the aralysis and interpretation of basic water-resource data are applied to water problems. Special emphasis is given to ground-water problems and to summarizing data that are useful to water managers in developing and utilizing ground-water supplies in the area.

Geologic investigations in the area provided data to describe the natural environment in which the hydrologic cycle operates. Hydrologic and hydraulic studies resulted in knowledge of the occurrence and movement of water within the area. The types of basic data include determinations of physical and hydrologic characteristics of soil and rock, determinations of streamflows and ground-water levels, determinations of temperature, and the physical and chemical properties of waters. Correlations of the basic data with natural phenomena, such as precipitation, and with changes in the environment imposed by man delineate the water regimen and relate the 1 ydrologic system to the development and conservation of Louisville's water resources.

\section{RESULTS OF INVESTIGATIONS}

Most of the data collected and analyzed during investigations of ground-water resources in the Louisville area since 1943 aro incorporated in Geological Survey reports resulting from those invertigations. Before the 1950 's, the reports were generally released to open file and duplicated in limited quantities. A tropical summary of basic groundwater information is given in table 1.

\section{COOPERATION AND ACKNOWLEDGMENT:}

The U.S. Geological Survey in cooperation with city, county, State, or Federal agencies, and currently in cooperation with the Kentucky Geological Survey, has been active in water-resources investigations in the Louisville area since 1938. Intensive studies of gro'und-water resources in the area began in 1943 in cooperation with the Geological Division, Kentucky State Department of Mines and Minerals (now the Kentucky Geological Survey, a research and service department of the University of Kentucky), and with the city of Louisville. The studies were continued in cooperation with Jefferson County, the Rubber Reserve Company (a wartime agency of the Federal 


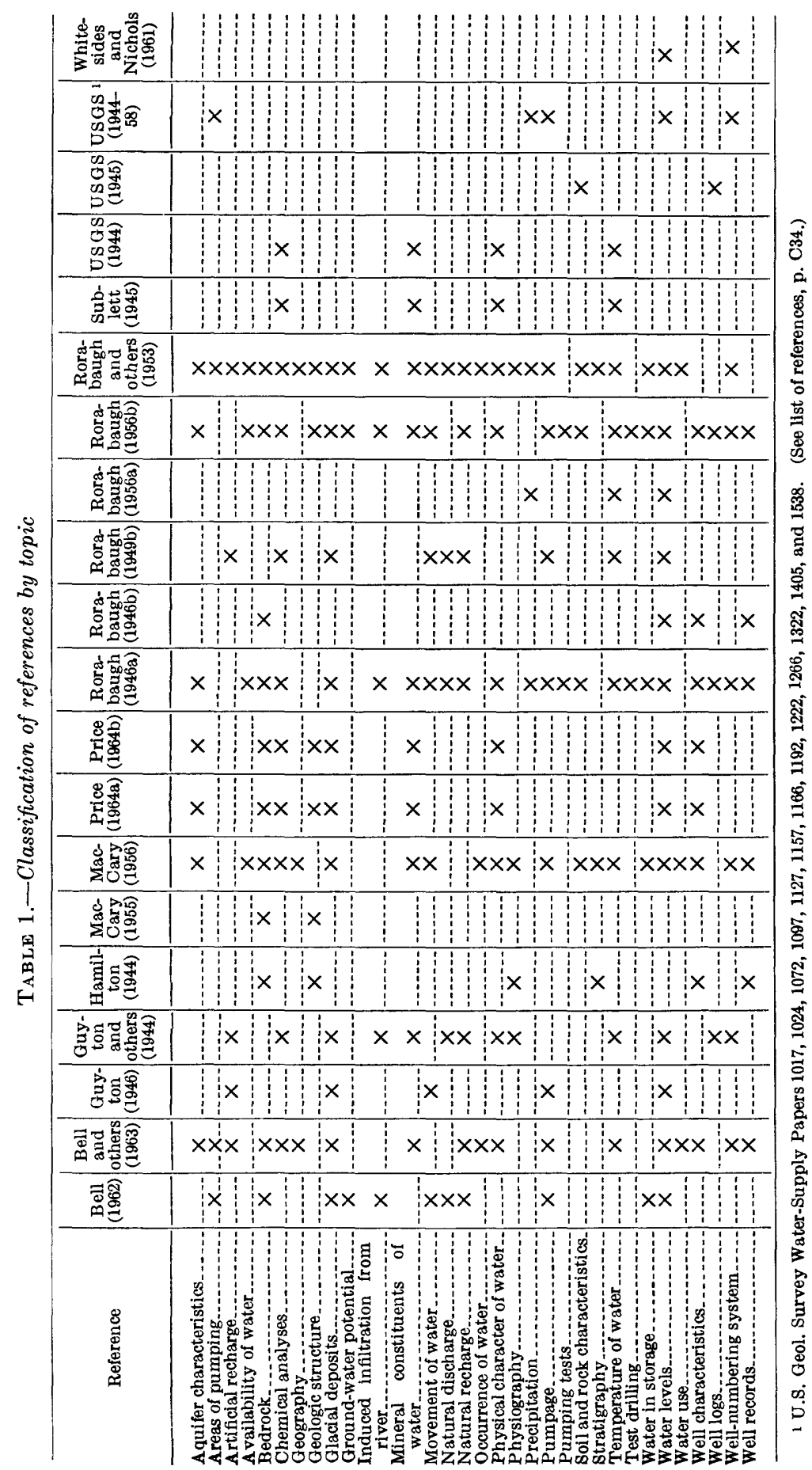


Government), the city of Louisville, and the Economic Development Board of Kentucky (formerly the Agricultural and Industrial Development Board) and are currently in cooperation with the Kentucky Geological Survey.

Most of the data used in this report were collected by the U.S. Geological Survey during the period 1943-62. However, much information was furnished by other Federal agencies, State, county, and city officials, well drillers, industrial managers, and many individuals too numerous to list, who also permitted the Survey to make observations and to collect data at many installations.

\section{WELL-NUMBERING SYSTEM}

The Louisville area lies between long. $85^{\circ}$ and $86^{\circ} \mathrm{W}$. and lat. $38^{\circ}$ and $39^{\circ} \mathrm{N}$. and has been subdivided into quadrangles by a grid of 1-minute meridians of longitude and 1-minute parallels $\mathrm{c} f$ latitude. The wells in each of the quadrangles are numbered in the order inventoried. A well is designated by a composite of three numbers: the first, indicates the minutes of longitude; the second, the minutes of latitude; and the third, the number of the well in that quadrangle. Thus, well 43-15-1 is the first well inventoried in the 1-minute quadrangle west of long. $85^{\circ} 43^{\prime} \mathrm{W}$. and north of lat. $38^{\circ} 15^{\prime} \mathrm{N}$.

\section{DESCRIPTION OF THE AREA}

The Louisville area, as described in this report, includes all Jefferson County (fig. 1) an area of 394 square miles in the north-central part of the State. It is in the drainage basin of the Ohio River, which forms the west boundary of the area. The climate is mild and humid, and extreme conditions seldom prevail for long periods. The Population Committee of the Louisville Chamber of Commerce estimated that the present (1963) population of 650,000 is expected to increase to about 745,000 by 1970 . Industrial and commersial enterprises are the basis of a stable economy. Farming, principally in the eastern part of the county, is less significant in the general economy of the area. Adjustments after World War II included an expansion of industry and a shift of the increasing population from city to outlying areas.

\section{THE HYDROLOGIC SYSTEM}

The dominant feature of the hydrologic system in the Louisville area is the Ohio River and its flood plain underlain by about 100 feet of permeable sand and gravel deposits. At Louisville the river carries the drainage from an area of 91,170 square miles. The river fur- 


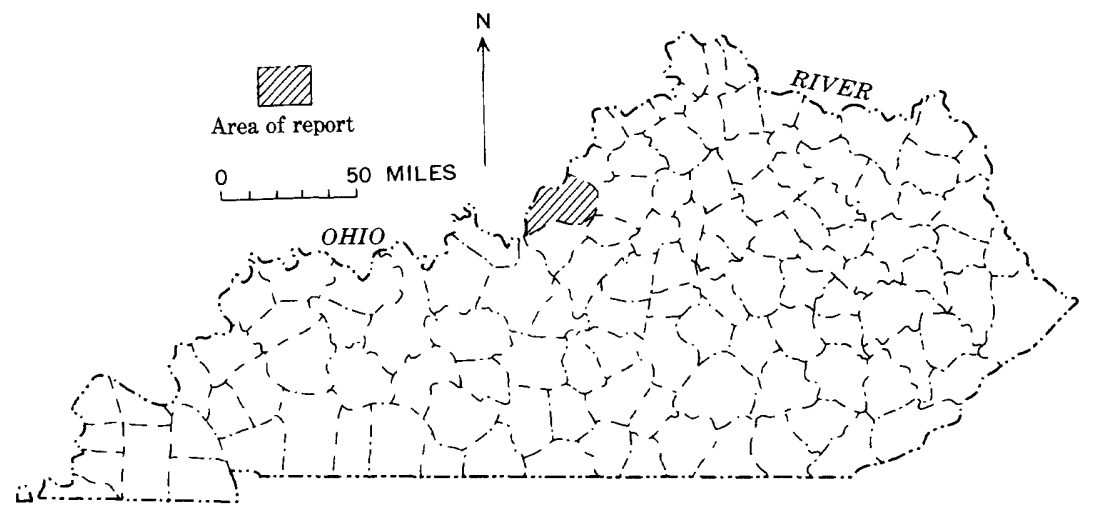

Fraure 1.-Area covered by this report.

nishes water suitable for all local uses, provides a navigation avenue for 80 million tons of freight annually (1959-61), and provides recreational areas. The average discharge of the river at Louisville is so large-113,900 cfs (cubic feet per second), or more than 73 billion gallons per day-that a water shortage seems inconceivable. Despite the abundance of water, its chemical and biological quality is affected by contamination from untreated domestic sewage and industrial wastes discharged into the river upstream from Louisville.

The smaller streams in the Louisville area, which all flow directly or indirectly into the Ohio River, are relatively unimportant as sources of water because their flows in dry years become very low or cease entirely.

The part of local precipitation that does not become surfac? runoff or is not evaporated enters the ground and replenishes soil moisture or seeps further downward to the zone of saturation and recharges the ground-water reservoirs. Ground water in the area is dis?harged through wells and springs or moves generally westward and northwestward where it seeps into the river or leaves the area as sulssurface underflow. Figure 2 is a generalized diagram showing the occurrence and direction of movement of waters in the Louisville area.

\section{GEOLOGIC FRAMEWORK}

The geologic framework that controls the availability of water in the Louisville area is illustrated by the block diagram (pl. 1). The upland areas are underlain by shale and limestone of Silurian, Devonian, and Mississippian ages. These rocks dip to the soutl west at about 40 feet per mile. The present valley of the Ohio River along the western and northwestern part of the area was cut into the shale and 


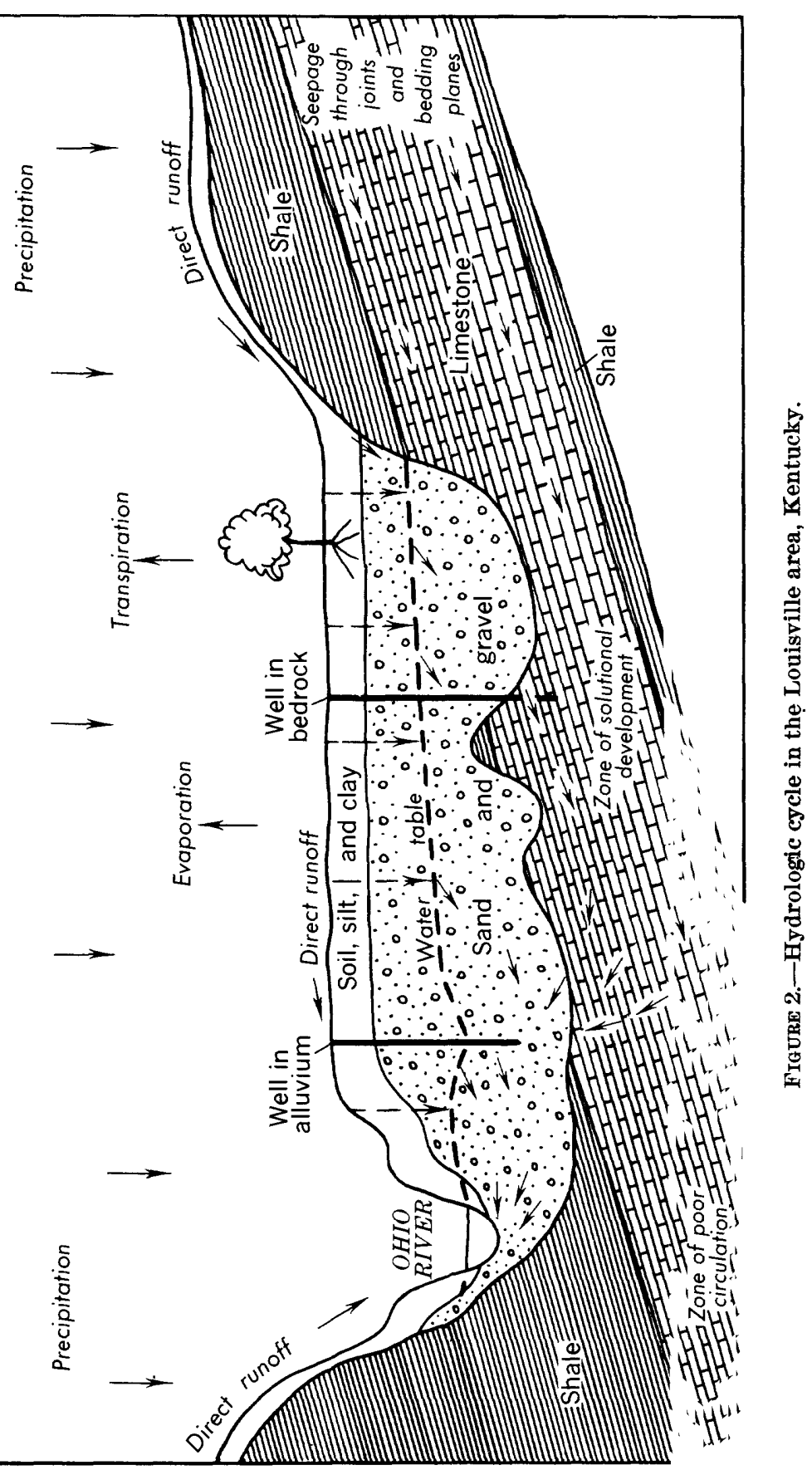


limestone during glacial times. The rock valley is filled with alluvium of Quarternary age which underlies the Ohio River flood plain to a maximum depth of 130 feet. (In this report, the Ohio Rirer flood plain is defined as the entire surface area of the alluvium filling the rock valley.) The alluvium consists of glacial outwash, sand, and gravel and a blanket of Recent silt and clay, and is connected hydraulically with the Ohio River along much of its course in the area.

The glacial deposit of sand and gravel in the flood plain has a vast water-storage capacity and high transmissibility and is the principal aquifer in the Louisville area. The limestone provides a secondary aquifer, particularly where solution openings occur along extensive joint systems and well-formed bedding planes. Limestone ir the central part of Jefferson County yields water to many domestic wells, and the limestone bedrock beneath the glacial sand and gravel in the city yields large quantities of water to industrial wells.

The clay and shale are not significant as aquifers but are important because they influence the flow of water to and from other formations.

Formations of Ordovician and Silurian ages are exposet in the eastern third of the county. Formations of Mississippian age comprise the bedrock of the Knobs area in the southwestern part of the county. These formations, however, are not of hydrologic importance locally and are not defined in the local hydrologic system.

\section{HYDROLOGY}

The Louisville area is at times affected by cold airmasses from the northwest and Great Lakes area, by the warmer air sweeping up the Mississippi and Ohio Valleys from the Gulf region, and by the meeting of these two opposing airmasses. The resulting variation in precipitation affects the local hydrologic system.

The normal annual precipitation at Standiford Airport (U.S. Weather Bur. records) for the period 1931-60 is 41.32 inches. (See fig. 3.) If it is assumed that this amount is the average throughout the Louisville area and that losses to evaporation and transpiration are about 60 percent of the precipitation, an average of nearly onethird of a billion gallons is added daily to the amount of water that moves through the area, either on or in the ground. This is less than one-half of 1 percent of the average amount of water that the Ohio River brings in from outside the area each day.

In the eastern third of Jefferson County and in the Knobs area south of Louisville, topographic highs and lows are pronounced, and much of the precipitation leaves the area rapidly as overland runoff to local streams. Only a small amount of water seeps below the soil mantle 


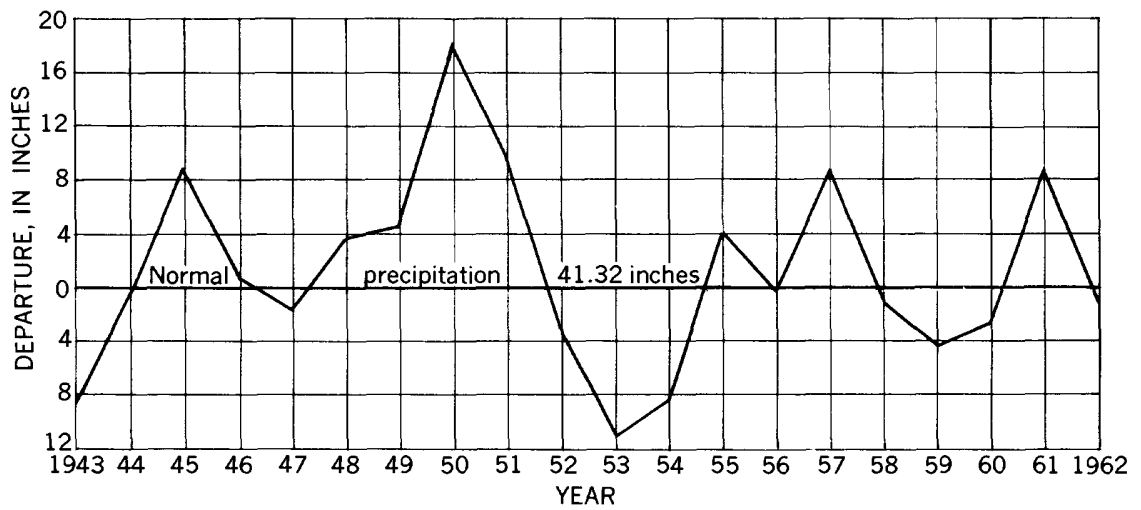

Figure 3.-Departure from normal precipitation at U.S. Weath?r Bureau station, Louisville, Ky., 1943-62. Normal precipitation determined by U.S. Weather Bureau, based on period 1931-60.

to the underlying limestone. In the central part of the cointy, and extending to the Ohio River valley, the relief is relatively flat, the runoff is generally slower, and recharge to ground-water storage in the underlying limestone is substantially higher. Ground-rater flow is generally toward the Ohio River valley except in the extreme eastern part of the county where the flow is toward the south.

In the flood plain the many buildings and great amount of pavement limit the area in which water can enter the ground; alsc. the low permeability of a silt-and-clay blanket impedes downward seepage of water into the more permeable sand and gravel. Consequently, direct recharge of the alluvial aquifer by precipitation is decreased. Infiltration from the Ohio River in the northeastern part of Louisville and flow through the rock valley wall are major contributors of water to the sand and gravel. The deposit of sand and gravel with its vast storage of water, estimated to be nearly 100 billion gallons (Bell, 1962), supplies many industrial wells in the area and is the source of water for the Louisville Extension Water District in the southwestern part of the county.

Water in the area is predominantly of calcium magnesium bicarbonate type and contains appreciable concentrations of sulfate. Ground water is generally harder than surface water and contains more dissolved solids.

\section{RELATION OF HYDROLOGIC SYSTEM TO WATER UTILIRATION}

The Louisville area has an abundant water supply: Its optimum use is controlled primarily by the (1) variation of precipitation (seasonal and local), (2) hydrologic character of soil and rock, and (3) dynamics of fluid flow. 
Seasonal and local variations in precipitation directly affest availability of water outside the flood plain. During dry summers most of the small streams and many wells finished in the limestone become dry, making it necessary for users to store water or to import it. Seasonal variation is also noted in the flood plain, but it is small compared with the total amount of water available, and no critical shortage occurs there.

The porosity of soil and rock determines how water right be absorbed and accumulated in the ground. The permeability, or watertransmitting capacity, determines the quantity of water that vill move through the rocks and can be utilized. An abundance of ground water is available in the porous and permeable sand and gravel deposits in the Ohio River flood plain. Only small amounts of ground vater are available from the less permeable limestone of the uplands.

Water on the surface and in the ground moves down a tydraulic gradient. Water on the surface, unless stored in the area of use, runs away rather quickly to the Ohio River and its flood plain. Mechanical energy must then be provided to move the water to the ares of use. Downgradient movement of water through cracks in limestone and pore spaces in the sand and gravel, however, is slower, and the water is held in storage for longer periods of time. Thus storage is provided naturally, and the water is available in the area where it is to be used. Industrial pumping of water at high rates from the alluvium in parts of the Louisville area has altered the hydraulic gradients which influence the direction of flow and locally limit the utilization of ground-water supplies.

The chief adverse effect of water use on the local hydrologic system is pollution. Because the Louisville area obtains most of its water from the Ohio River, its problems of chemical and biological pollution originate in upstream areas. Therefore, extensive treatment of water is required to control the quality for domestic and industrial uses.

\section{THE AVAILABLE WATER SUPPLY}

The large quantity of water that flows in the Ohio River and moves through the alluvial sand-and-gravel deposit in the Ohio River flood plain at Louisville is the major source for development in the area. The availability of adequate public and industrial water supplies contributes much to Louisville's economic growth and to tho welfare of its population. Sources of smaller supplies are the tributary streams (mainly Beargrass Creek, Floyds Fork, Harrods Creek, and Pond Creek) which drain the various parts of the county and the ground water contained in the bedrock of the uplands. 


\section{THE OFIO RIVER}

The Ohio River has provided the municipal water supply for more than a century, and it provides most of the water for all other uses including industrial supplies, fire protection, irrigation, nevigation, hydroelectric power, recreation, and dilution of wastes. It also carries away local surface drainage and supports fish and wildlife. But in contrast to the many benefits it provides, the Ohio River has been a relentless force of destruction during severe flooding.

\section{DISCHARGE}

Although the average flow of the Ohio River at Louisville $(114,000$ cfs, or 73 billion gallons per day) equals more than half the average flow over Niagara Falls, it cannot be used to provide a basis for determining water-supply availability. Evaluations must be b'sed primarily on data showing the magnitude and frequency of minimum flows and to some extent on duration-of-flow data.

The duration curve of flow (fig. 4) shows the percentage of time that the daily flow of the Ohio River at Louisville exceeds various values. The shape of the curve is indicative of the flow characteristics of the drainage basin. The graph (fig. 4) shows that the discharge equaled or exceeded 3.88 billion gallons per day 99 percent of the time during the period 1928-62 and that the discharge equaled or exceeded 73 billion gallons per day (the average flow) about 37 percent of the time. The minimum daily flow was less than 3.88 billion gallons per day at an average interval of 2.7 years (fig. 5 ).

The low-flow frequency curves shown on figure 5 were derived from the daily flow records at Louisville for the period 1928-62.

These curves represent the average of plotted points computed from the lowest mean flows for periods of 1 day, 7 days, and 30 consecutive days in each year of record. The curves show the expected recurrence interval in years for the indicated minimum flows.

The low-flow frequency curves show that on the average of every 20 years the flow of the Ohio River at Louisville recedes so that the lowest mean flow for 30 consecutive days will be less than $7,007 \mathrm{cfs}$, for 7 consecutive days will be less than $5,500 \mathrm{cfs}$, and for 1 day will be less than 4,100 cfs.

The minimum flows shown for the year 1930 (30-day low flow, 4,320 cfs; 7-day low flow, 3,530 cfs; 1-day low flow, $2,100 \mathrm{cfs}$ ) are extremely low as compared to the frequency curves. An analysis of the plotting indicates that the 1930 drought was a very unusual occurrence and that the recurrence expectancy of minimum flows comparable to those in 1930 will be a long period of years, possibly many times the period of record used. 


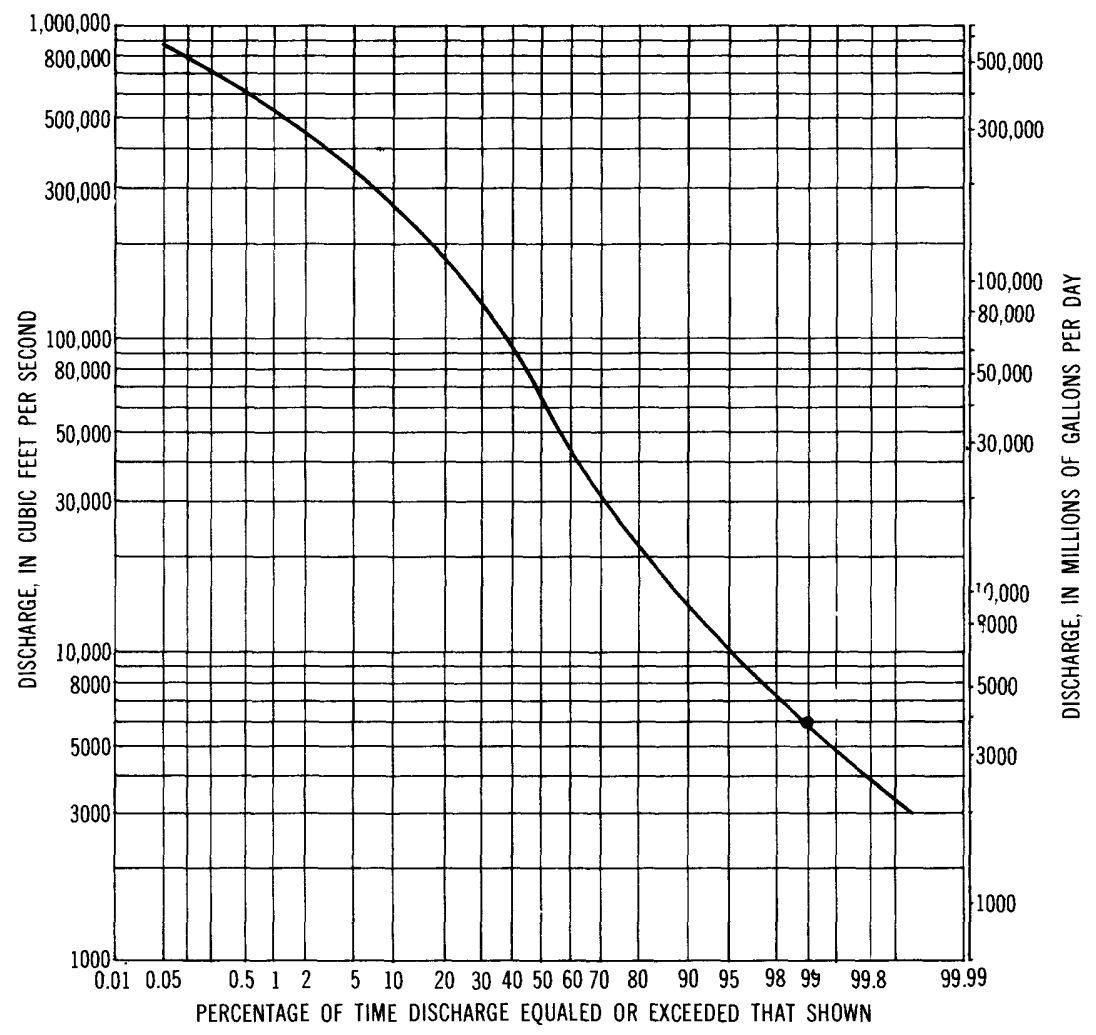

Figure 4.-Duration curve of daily flows, Ohio River at Louisville. Ky., 1928-62. Drainage area 91,170 square miles. Example: The daily flow at Louisville equaled or exceeded $6,000 \mathrm{cfs}(3,878 \mathrm{mgd}) 9 \varepsilon$ percent of the time during the period 1928-62.

In evaluating the potential water supply of the Ohio Piver at Louisville, it is noted that the Louisville Water Company reported an average daily pumpage of $135 \mathrm{cfs}$ from the Ohio River in 1963 and a maximum daily pumpage of $195 \mathrm{cfs}$ in 1962 . Compared to the 20-year flow expectancy, the average daily pumpage for 1963 represents only 4 percent of the minimum daily flow expected and less than 3 percent of the 7-day minimum flow. The maximum daily pumpage of $195 \mathrm{cfs}$ in 1962 represents only 5 percent of the 20-year minimum daily flow and less than 4 percent of the 20-year 7-day minimum flow. Even during the extreme drought of 1930 the maximum daily pumpage would have been only about 9 percent of the minimum daily flow and less than 6 percent of the 7-day minimum flow.

Another factor used in evaluating the future water-supply potential of the Ohio River is the effect of releases from storage raservoirs 


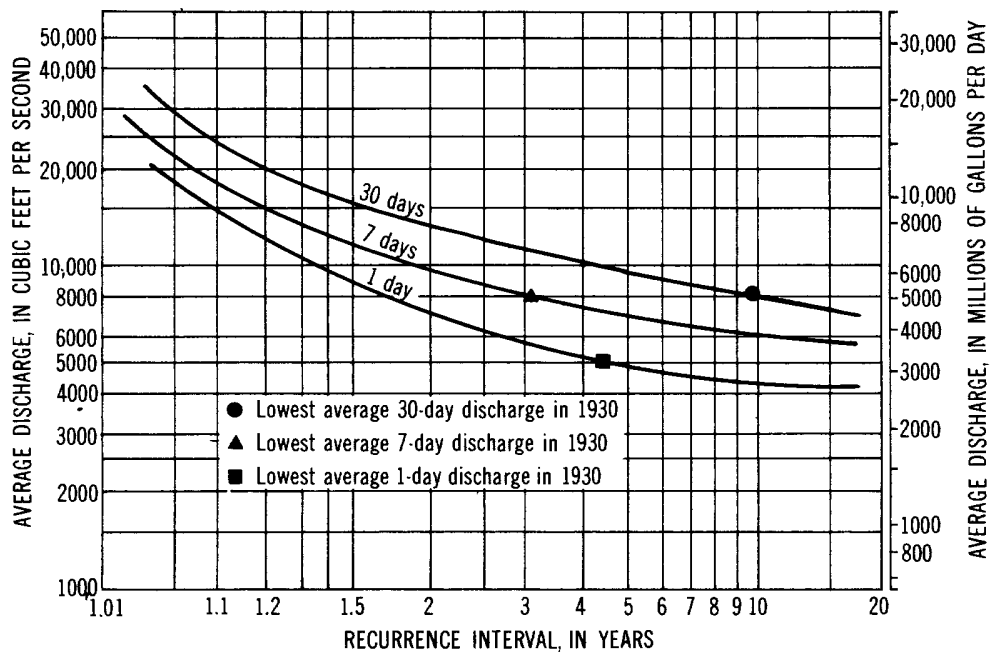

Figure 5.-Low-flow frequencies, Ohio River at Louisville, Ky., 192862. Drainage area 91,170 square miles. Examples: (1) Th? minimum daily flow at Louisville will be less than $5,000 \mathrm{cfs}(3,232 \mathrm{rngd})$ at average interval of 4.5 years, (2) The minimum 7-day flow will be less than $8,000 \mathrm{cfs}(5,170 \mathrm{mgd})$ at average interval of 3.2 years, (3) The minimum 30-day flow will be iess than $8,000 \mathrm{cfs}(5,17 \mathrm{mgd})$ at average interval of 9.7 years.

upstream from Louisville in the four-State area of Pennsylvania, Ohio, West Virginia, and Kentucky. It has been estimated that the reservoirs on tributary streams in those States, including th ose reservoirs completed in recent years, would augment Ohio River flows at Louisville by as much as 50 percent during minor droughts and that, on recurrence of an extreme drought similar to that in the 1930's, releases from the reservoirs would double the minimum flows at Louisville.

\section{ChEMICAL QUALITY AND POLLUTION}

The water in the Ohio River under natural conditions would be slightly hard and of the calcium bicarbonate or calcium magnesium bicarbonate type. However, because of pollution by industrial and domestic wastes, the concentrations of sodium, sulfate, chloride, fluoride, nitrate, and the hardness are increased and the basic character of the water is changed. In addition, oils, toxic substances, and tasteand odor-producing compounds are discharged into the river from various sources. Also, there is considerable variation in the chemical quality owing to changes in riverflow and in the amounts of the pollutants entering the stream. As a result, treatment is required to make the water suitable for human consumption and for some indus- 
trial uses. The amount of treatment necessary varies seasonally with the variation in riverflow and locally with the change in the volume of waste entering the stream.

In 1961 the water of the Ohio River had an average hardness of $137 \mathrm{ppm}$ (parts per million), as reported by the Ohio River Valley Water Sanitation Commission (ORSANCO). The hardness ranged from 93 to $197 \mathrm{ppm}$. Total dissolved solids ranged from 150 to 334 $\mathrm{ppm}$ and averaged $214 \mathrm{ppm}$. The total dissolved solids were well below the 500-ppm limit recommended by the U.S. Public Health Service (1962) in a year when riverflows were above normal.

There is also considerable variation in bacterial pollution. During 1961 ORSANCO reported that coliform bacteria ranged from 1,100 to 13,000 (most probable number per $100 \mathrm{ml}$ ). In relation to previous years this range is low and is the result of the river cleanup by ORSANCO and of dilution by the above-normal riverflow in 1961 .

The quality of the water in the Ohio River at Louisville in 1961, as reported by ORSANCO, is summarized in the following table.

\begin{tabular}{|c|c|c|c|}
\hline \multirow{2}{*}{ Constituent } & \multicolumn{3}{|c|}{ Concentration (ppm) } \\
\hline & Maximum & Minimur & A verage \\
\hline 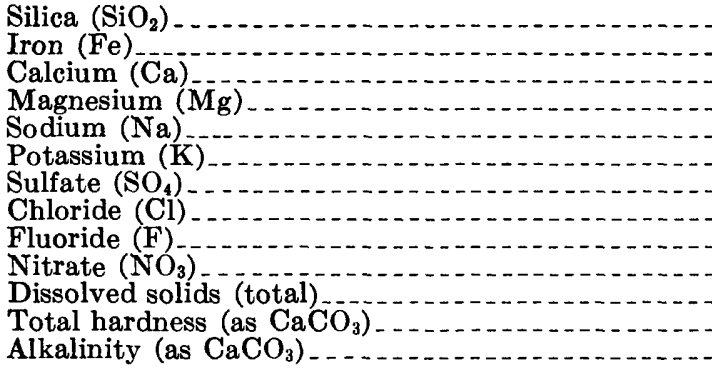 & 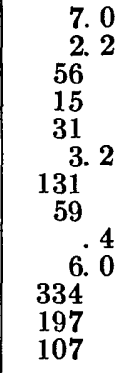 & $\begin{array}{r}2.4 \\
28 . i \\
7 . i \\
6 . \stackrel{i}{i} \\
38.9 \\
8.0 \\
2.0 \\
150 \\
93 \\
49\end{array}$ & $\begin{array}{l}5.6 \\
39 \\
10 \\
15 \\
2.1 \\
74 \\
24 \\
.2 \\
4.0 \\
214 \\
137 \\
74\end{array}$ \\
\hline $\begin{array}{l}\text { Specific conductance } \\
\text { pH } \\
\text { Temperature }\end{array}$ & $\begin{array}{l}543 \\
8.8 \\
81\end{array}$ & $\begin{array}{l}243 \\
6.7 \\
35\end{array}$ & 351 \\
\hline
\end{tabular}

SMALL STREAMS

An average of about 15 inches of the annual precipitation (Rorabaugh and others, 1953, p. 6) in the Louisville area becomes runoff. The total drainage, averaging more than 0.2 billion gallons per day, is carried to the Ohio and Salt Rivers by tributary streans, principally Floyds Fork in eastern Jefferson County, Harrods Creek and Beargrass Creek in the north-central part of the area, and Pond Creek in the southern and western parts of the county. These streams provide recreational areas and furnish some water for stock and for 
irrigation, but their flows are not adequate for dependable supplies. During the late summer and fall, the flow of these streams usually recedes to a very low quantity, sometimes going dry for periods of a few days to several weeks. In recent years, however, the flow of Pond Creek has been augmented by inflow diverted by manufacturing plants from the Louisville public water supply.

Ponds for stock are necessary on most farmlands in Jefferson County. As more land is developed for housing, the stock ponds are gradually disappearing and are becoming less important in the general water regimen. In contrast, artificial lakes formed br stream impoundments are becoming more important as recreational areas for fishing and water sports.

\section{GROUND WATER IN ALLUVIUM}

The occurrence and availability of water in the Louisville area are described by Rorabaugh and others (1953), by MacCary (1956), and by Bell and others (1963).

The alluvium in the Ohio River flood plain is the second most important source of water. It comprises outwash sand and gravel of Pleistocene age ranging from 0 to 100 feet in thickness, overlain by a blanket of silt and clay as much as 40 feet thick. Very thin deposits of clay and silt of Recent age cover parts of the flocd plain. The permeability of the top clay and silt is low and impedes vertical seepage of water from the surface. Nevertheless, the glacial deposit of sand and gravel is a good, permeable water-bearing formation, and the entire thickness is considered a single hydrologic unit. The thickness of the saturated sand and gravel varies considerably (pl. 2) because of the shape of the underlying bedrock surface and because of the lowered water table in heavily pumped areas (pl. 3).

The alluvium northeast of downtown Louisville between the Ohio River and the rock bluffs is mostly saturated. Along the reach northeast of Zorn Avenue, the alluvium ranges in thickness from about 120 feet near Goose Creek to about 90 feet at Zorn Avenue and sverages about 100 feet in thickness (pl. 2). The water in the alluvium along the reach is connected hydraulically with the river, and chenges in the river stage are reflected rapidly by corresponding changes in ground-water storage.

Southwest of Zorn Avenue the hydraulic gradient generall slopes toward downtown Louisville where water levels have been lowered by pumping for air conditioning (pl. 3). From downtown Louisville the gradient steepens progressively toward the heavily pumped industrial center southwest of the city. The average thickness of the alluvium within the city limits is greater than in the reach along the 
river northeast of Zorn Avenue, but the thickness of saturated sand and gravel is less because of the lowered water table.

Southwest of downtown Louisville ground water flows northwestward toward the heavily pumped industrial center and westward toward the Ohio River. A large quantity of ground water is available, but the thickness of saturated sand and gravel varies considerably because of several domes in the underlying bedrock.

Southward from Bells Lane to Lees Lane the gradient is from the river toward heavily pumped centers where the water level has been drawn down below river level. South of Lees Lane the gradient is toward the river, except during floods. Although the potential is not so great as that northeast of the city, much infiltration can be induced from the river along its reach south of Lees Lane.

Bell $(1962$, p. 17) estimated that the maximum supply that could be developed in the alluvial aquifer of the flood plain in the Louisville area without depletion of storage is about $370 \mathrm{mgd}$ (millior gallons per day). However, to attain that supply, maximum infiltration from the Ohio River would have to be induced. This would require infiltration galleries or high-capacity wells virtually along the ent re reach of the river where it is connected hydraulically with the aquifers.

The river is connected hydraulically with the alluvial aquifer, in varying degrees of effectiveness, along most of its distance within the Louisville area (pl. 2). The most effective connection-and I ance the greatest potential infiltration that could be induced from the riveris along the reach northeast of Zorn Avenue. The hydraulic connection between the river and aquifer becomes progressively less effective downstream toward McAlpine Dam because of clay barriers. In the northwestern part between McAlpine Dam and Bells Lane, except in a small area of low permeability opposite Sand Island, the ccnnection is poor. The infiltration potential is large southward from Bells Lane.

A large amount of water stored in the alluvium underlying the Ohio River flood plain is a reserve ground-water supply that could be drawn in emergencies. Bell (1962, p. 22) estimated that nearly 1CO billion gallons are stored in the alluvium within the Ohio River flood plain of the Louisville area.

\section{NATURAL RECHARGE TO THE ALLUVIUM}

Natural recharge, which is nature's way of maintaining or replenishing ground-water supplies, is derived from precipitation. Some rain falling in areas where permeable rock, chiefly limestone, crops out, fills the crevices and voids of the rock and flows by gravity from the limestone into the alluvium. Elsewhere, direct downward seepage of local rainfall through the permeable alluvium adds to the ground- 
water storage. Natural recharge to the alluvium in the flood plain of the Louisville area, therefore, is partly by flow through the permeable rocks of the uplands adjacent to the deposits of sand and gravel and partly by direct downward seepage. Rorabaugh (1949b, p. 20) estimated that flow through the valley wall northeast of Beargrass Creek in 1946 was about 200,000 gpd (gallons per day) per mile of valley wall and southwest of Louisville in 1945 was about 107,000 gpd per mile of valley wall. The flow through the valley wall ir the strip between Beargrass Creek and Shively should be as great or greater than in the other areas because of the predominance of limestone and the steeper hydraulic gradients toward the sand and gravel. Because of hydrostatic pressure some water moves upward from limestones underlying the alluvium, particularly in the west-central subarea.

The natural recharge by downward seepage to the alluvium is impeded by the considerable thickness of clay overlying the deposit of sand and gravel and is further minimized in the city because of buildings and pavings. Neverthless, there are substantial amounts of recharge to the alluvium outside the built-up area. Accretion to the aquifer in the area southwest of Louisville was estimated by Rorabaugh $(1949 \mathrm{~b}$, p. 21 ) as about 250,000 gpd per square mile in 1945 , which was a wet year, but it would be much less in dry years. The changing use of land caused by urbanization in that part of the Louisville area has probably reduced the direct recharge from rainfall penetrating the flood plain. Supplementary recharge at tim es has resulted from an accumulation of runoff in large open pits that were excavated for various purposes.

\section{INDUCED RECHARGE TO THE ALLUVIUM}

In addition to the natural recharge to the area, a large amount of water can be induced by infiltration from the Ohio River. If highcapacity wells very near the river are pumped at high rates over a long period of time, the steep hydraulic gradient that is created will induce a large amount of water to flow through the banks and bed of the river. Rorabaugh (1956b, p. 159) estimated that about $280 \mathrm{mgd}$ could be induced by infiltration from the river northeast of Zorn Avenue and (Rorabaugh, 1949b, p. 5) about $59 \mathrm{mgd}$ from the reach south of Lees Lane.

\section{NATURAL DISCHARGE FROM THE ALLUVIUM}

All the recharge to the ground water in the alluvial area is not a net gain because water moves downgradient through the aquif $\rightarrow r$ and is discharged through seeps along the banks of streams or joins the underflow through the aquifer out of the area. The normal lydraulic gradient of ground water between Zorn Avenue at the Orio River corresponds to the difference of head in the river between the upper 
and lower pools at Louisville. Most of the natural discharre from the alluvium is lost to the Ohio River south of Lees Lane. The loss in 1945 was estimated by Rorabaugh $(1949$ b, p. 4$)$ to be about 800,000 gpd per mile of river.

\section{CHEMICAL QUALITY AND TEMPERATURE}

Throughout the area the quality of the water in the alluvium varies depending on the nearness of the alluvium to sources of recharge or pollution. Water from alluvium is generally very hard, high in bicarbonate, and contains dissolved solids ranging from 250 to more than $1,500 \mathrm{ppm}$. The most highly mineralized water is in the central and west-central parts of Louisville where the alluvium is underlain by limestone. The median hardness of water from wells in deposits of sand and gravel overlying limestone bedrock sampled in 1952 was 642 ppm; from wells in sand and gravel overlying shale, $470 \mathrm{ppm}$ (Rorabaugh and others, 1953, p. 37). Without softening, ground water from alluvium is not satisfactory for many purposes and is unacceptable for most industrial uses.

The chemical characteristics of water from wells finished in the alluvium and in the underlying bedrock are shown on plate 4 by polygons, called Stiff diagrams. The polygons are formed by plotting on four parallel horizontal axes the cations to the left and anions to the right of a vertical zero reference line. The concentrations for the cations calcium, magnesium, sodium, potassium, ${ }^{1}$ and iron and for the anions bicarbonate, sulfate, chloride, and nitrate are expressed in equivalents per million. Lines connecting the plotted points form a polygon which represents the chemical character of the water. The polygons show that this water is predominately a calcium bicarbonate type containing substantial magnesium and sulfate. The sodium, potassium, and chlorides are present in lesser amounts. The iron and nitrate, though generally found in concentrations less than $0.1 \mathrm{epm}$ (equivalents per million), are plotted because of their undesirable effect on water for certain uses.

In general, wells along the Ohio River yield water with less hardness and dissolved solids than those in the remainder of tho area-a condition reflecting the effect of recharge by floodwater and river water induced by heavy pumping. Normally, the dilution effects of river-water infiltration diminish rapidly as the distance from the river increases. The effect is generally noticeable only within 400 or 500 feet of the river. However, it is more pronounced in the area between the river and the "Rubbertown" and downtown subareas.

Ground-water temperatures are fairly constant and approximate the average air temperature. In the Louisville area the ground-water

\footnotetext{
1 Sodium and potassium are shown as one constituent.
} 
temperature averages about $58^{\circ} \mathrm{F}$ except where it is affected by river infiltration, by seepage from leaky sewers, or by artificial recharge. The temperature of water from wells ranges from $47^{\circ}$ to $6 f^{\circ} \mathrm{F}$.

\section{GROUND WATER IN BEDROCK}

The water-bearing properties of the principal bedrock formations in the Louisville area were described by Hamilton $(1944$, p. 9), by Rorabaugh (1949b, p. 20), and in more detail by MacCary (1956, p. 3).

The Louisville Limestone of Silurian age and the Jeffersonville and Sellersburg Limestones of Devonian age are exposed in the northern, central, and south-central parts of Jefferson County. They also underlie the valley fill under the central part of the city and are exposed in the riverbed at the Falls of the Ohio River. These formations form a single aquifer of secondary importance that yields most of the water pumped from consolidated rocks. Water in this aquifer is contained in and moves along interconnected cracks and solution channels.

In the uplands the ability of the limestone to transmit weter along joint systems, bedding planes, and solution openings is good, but its ability to retain or store water is low. The openings in the limestone are rapidly filled by downward seepage and lateral percolation. During wet seasons the limestone remains saturated, and large quantities of water are available. Between rains the limestone rapidly discharges water downgradient, and during droughts many of the solution channels at the higher altitudes are drained, causing shallow wells to become dry. However, many deep wells and springs at low altitudes in the uplands yield enough water for domestic use. The areal variation of available ground water is indicated by plate 5 .

This same limestone underlies much of the alluvium in the central part of the city. There, the solution channels are probably developed more extensively than in the uplands. The limestone beroath the flood plain is hydraulically connected with the deposits of sand and gravel, from which a continuing source of recharge is available, and consequently greater yields are available from the bedrock. Further, river water may enter the limestone bedrock at the Falls of the Ohio and flow southwestward along numerous narrow openings to areas of pumping. The most extensive joint system trends N. $30^{\circ} \mathrm{E}$.; the most productive wells in the limestone are in a well-defined belt that is parallel to the joint system and that traverses the northwestern part of the Louisville area (area 2, pl. 4). One rock well in this belt is 
reported to have yielded $1,100 \mathrm{gpm}$ (gallons per minute) for many years.

The water from the limestone bedrock is of the calcium bicarbonate type. It is generally very highly mineralized, but its minerel concentration varies greatly from place to place. The average hardness of water from 15 limestone wells beneath the alluvium of the Ohio River flood plain, sampled annually during the years $1944-52$, is $580 \mathrm{ppm}$ (Rorabaugh and others, p. 37). The hardness of the water from one of the wells sampled in 1953 was $1,140 \mathrm{ppm}$. The total dissolved solids in water from the limestone generally exceeded $1,200 \mathrm{ppm}$ and in one well was $1,480 \mathrm{ppm}$. The concentration of calcium, bicarbonate, and sulfate is particularly high.

\section{WATER-SUPPLY DEVELOPMENT}

The development of water supplies in the Louisville area is directly related to the growth of the city. Since 1858 when the Juouisville Water Company began pumping from the Ohio River for the public supply, developments have expanded to include several other river pumping stations for industrial uses and many wells for domestic and industrial uses.

The first extensive development of ground-water supplies was for air conditioning in downtown Louisville in the late 1930's. Development of ground-water supplies for industrial cooling, especially by manufacturers of chemicals and synthetic rubber, was greatest during the early 1940's. Most recently, the Louisville Extension Water District has developed a well field for public supply in the southwestern part of the county.

\section{UTILIZATION OF WATER}

Water in the Louisville area is used for public, commescial, and industrial supplies, for generation of electricity, and for irrigation and stock supply. It is withdrawn principally from the Ohio River and from the alluvium adjacent to the Ohio River (ground water). A small amount is withdrawn from small streams and ponds and from bedrock.

In 1962 water sources in the area furnished an average of 211.3 mgd of water for public and industrial uses. This excludes about 392 mgd of water which is diverted from the Ohio River for steam-generating plants and returned directly to the river, and a small amount of water pumped by privately owned wells and ponds for demestic and stock uses. The amount of water pumped for irrigation is not known but is probably small. 
The following table shows the average amount of water $\mathrm{u}^{\circ e d}$ daily in the area in 1962.

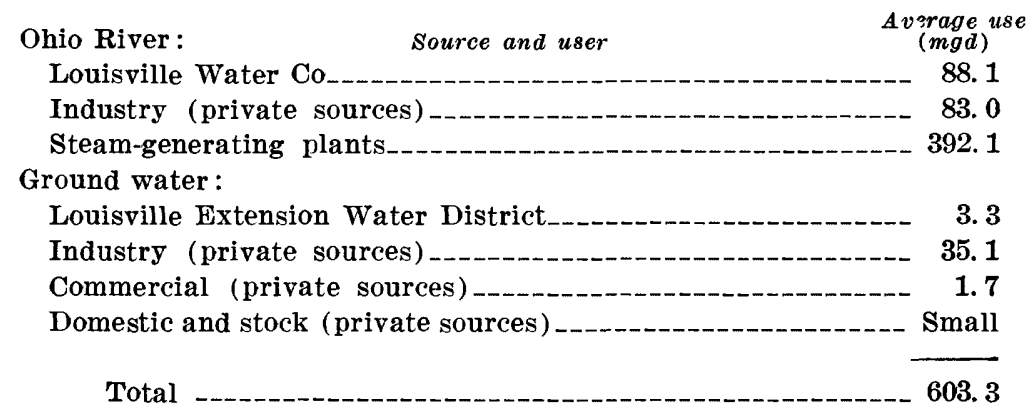

The distribution of pumping of ground water by industrial and commercial establishments is shown on figure 6 .

\section{EFFECTS OF WATER DEVELOPMENT}

The hydrologic cycle is a constant process, and some water from precipitation is continuously migrating toward areas of withdrawal to replenish the supply. Withdrawals in any part of the Louisville area will adversely affect the hydrologic system if they erceed the rate of replenishment. The effects may be felt in a number of ways, such as changes in water level, changes in water quality or temperature, and changes in the flow of a stream or yield of a well. Table 2 and plate 6 summarize these effects.

\section{CONDITIONS AFFECTING OPTIMUM DEVELOPMTNT OF WATER RESOURCES}

The Falls of the Ohio, a series of shallow rapids navigable only during periods of high-river stage, played an important part in the location of the city of Louisville. People and goods normally $\mathrm{rad}$ to be transported overland around the falls, and the stopping place grew into a river-trade town. Since that time the number and the complexity of water problems have increased with the population.

Optimum development of the water resources of the Louisville area depends chiefly on the ability of the water manager to cope with problems such as distribution of available supplies, flooding, croughts, quality of water and pollution, and drainage. An appraisal and analysis of Louisville's water problems are needed to plan the development and management of the water resources, particularly ground water. Development has reached a stage beyond which it should not progress without an orderly plan that will insure against waste and misuse. A shortage of water probably will never be a problem in the Louisville area owing to the abundance of water in the Ohio River and in the alluvium beneath the flood plain. 


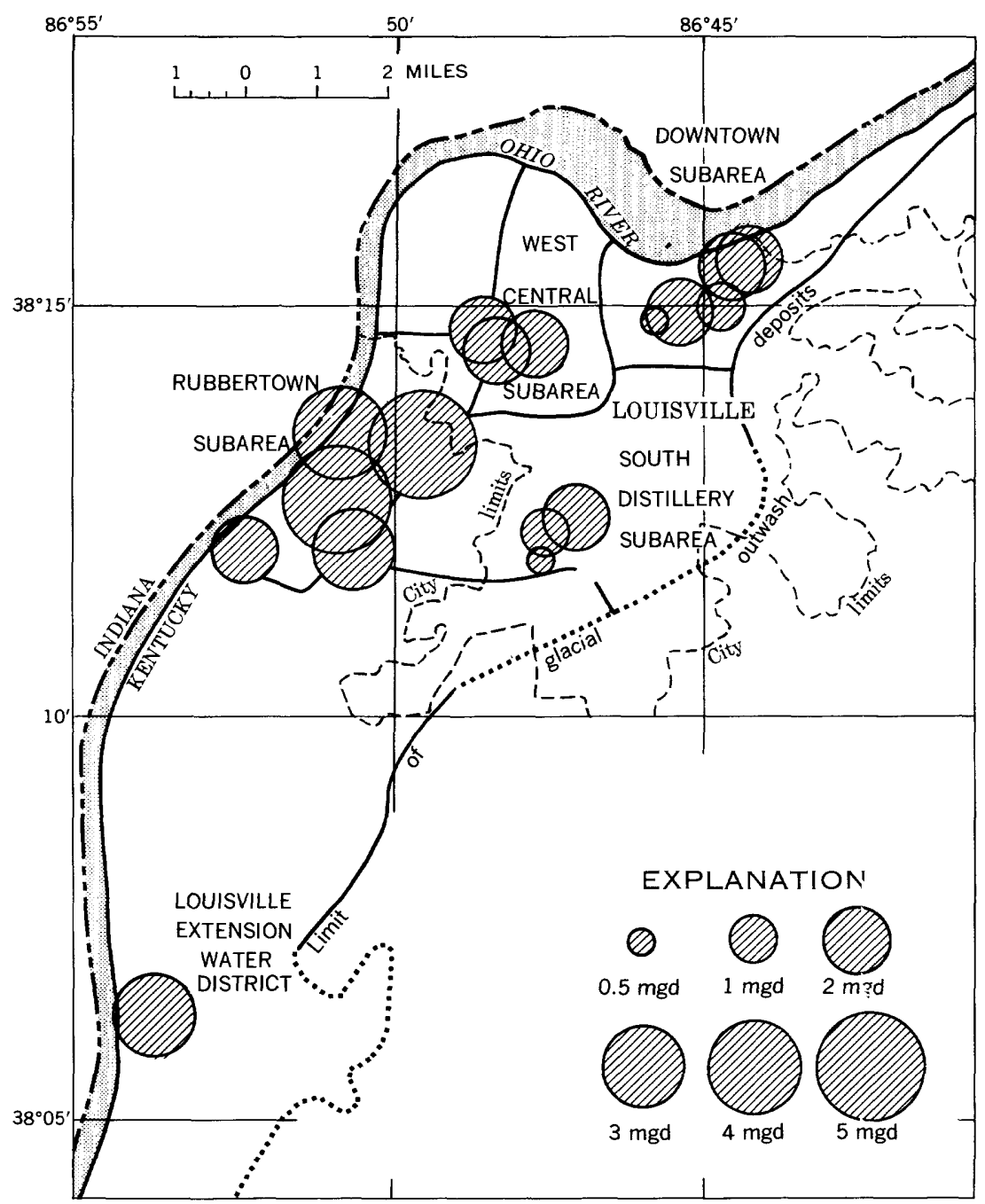

FIgURE 6.-Distribution of ground-water pumping in the Louisville area, 1962.

\section{DISTRIBUTION OF AVAILABLE WATER SUPPLIES}

The two major sources of water supply, the Ohio River and the alluvial deposits of the Ohio River flood plain, lie along the west border of Jefferson County, and water from these sources is directly available to only 15 percent of the county. Water is piped to the metropolitan and residential sections outside this area for municipal and industrial uses.

Ground water from wells and springs in the limestone of the uplands is generally adequate for farm and domestic supplies. However, dry 
C22 CONTRIBUTIONS TO THE HYDROLOGY OF THE UNITED STATES

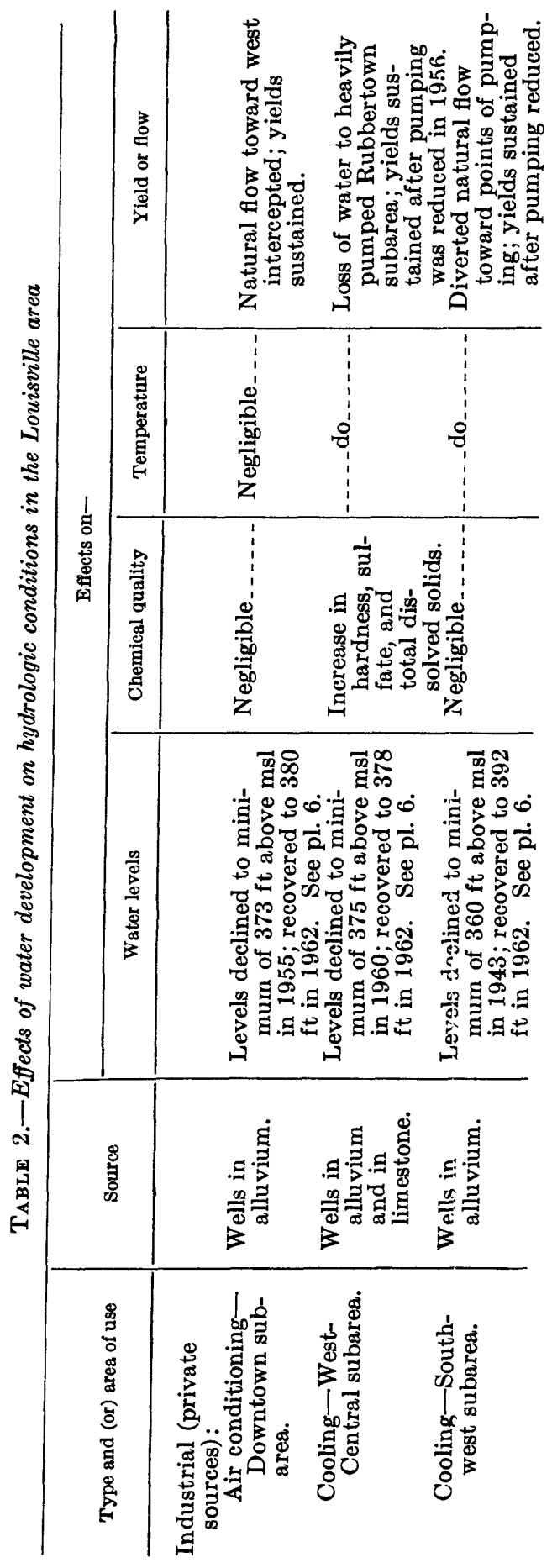



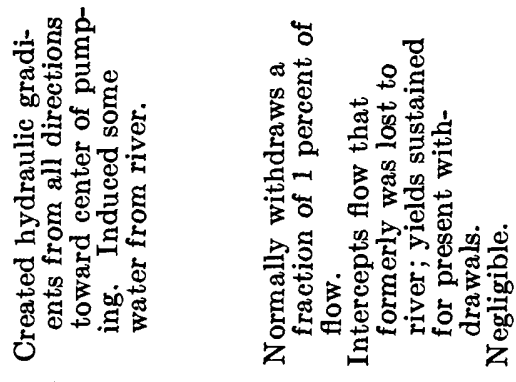

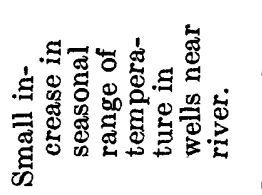

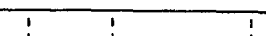

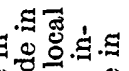

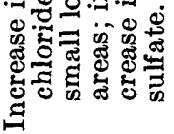

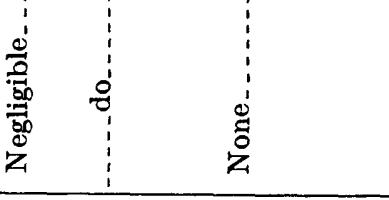

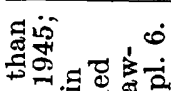
卷.

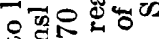

+ द्व 它坛 웛

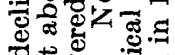

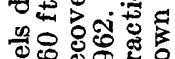

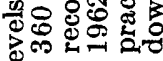
$\mapsto$

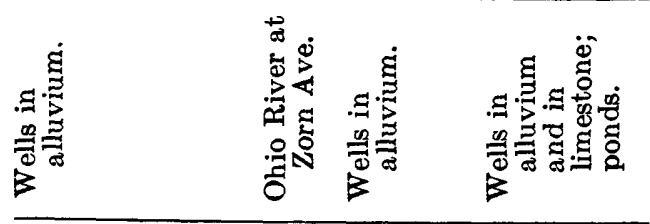

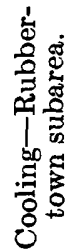
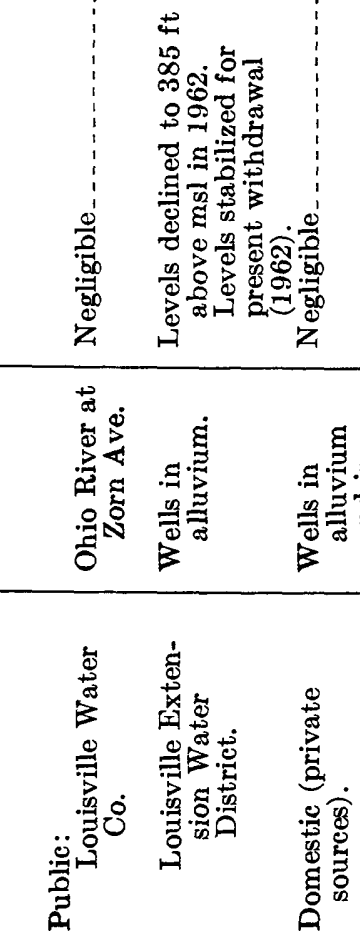

\section{幽}


holes and wells with inadequate yields have been drilled, and springs that dry up during late summer and fall are present throughout the area. Surface water from small tributary streams, such as Beargrass Creek and Floyds Fork, does not have a perennial flow and cannot sustain a continuous supply without impoundment.

\section{CURRENT CONDITIONS}

As a source of water supply, the Ohio River is relatively unaffected by seasonal fluctuations; high flows or flooding have no adverse effects on use, and minimum flows exceed the maximum daily withdrawal by many times. Consequently at no time is water from the Ohio River in short supply.

In the alluvial deposits of the flood plain, underlying abo't 15 percent of Jefferson County, seasonal variation in precipitation and the resulting change in river stage affect the amount of ground water in storage. Heavy rains and resulting high flows of streams during the winter and spring recharge these deposits. The total effect of the recharge, however, is not apparent until late summer and early fall, and during these periods the overall increase in storage may be somewhat obscured by heavy withdrawals for industrial and municipal supplies. During the late fall, when storage is at a minimum, heavy pumping for municipal and industrial uses in southwestern Jouisville has sometimes lowered the water table locally, giving cause for concern. No apparent problem of decreased supply has arisen in other areas of the alluvium.

In the uplands, which comprise approximately 85 percent of the county, the seasonal fluctuation of precipitation more directly affects the yield from wells and springs and the flow of streams than it does in the Ohio River bottom lands. In the uplands less water is stored because water moves rapidly through joints and solution openings in the limestone, and because stream gradients are steep, causing rapid runoff.

\section{AVAILABLE HYDROLOGIC DATA}

Data available for the Ohio River at Louisville consist of daily river stages collected since 1872 and daily discharges since 1928. These data show periods during which high and low flows are most likely to occur and their recurrence interval for the period of record to date. The data include the minimum-flow measurements needed as a base for planning withdrawals.

The hydrologic properties of the Ohio River alluvium rave been determined primarily from water-level measurements. At some wells the water-level measurements are made periodically, whereas at others they are made with continuous-recording gages. In specific areas 
pumping tests have been conducted under controlled conditions to measure the rate of change of water level with time at various pumping rates. These tests are useful in determining the coefficients of transmissibility and storage and the amount of water that can be induced from the Ohio River. Contours have been drawn on the water surface to show the actual position of the water table throughout the alluvial deposits. The water-level measurements are also used to determine the effect and time lag of high and low river stages and precipitation as well as the effect of nearby pumping wells.

Definition of water moving from the river to the alluvium or vice versa and the movement of water from the limestone of the upland into the alluvium are determined from a composite of both pumping tests and water-level measurements.

The present data on the alluvial area are adequate for most purposes, but continuation of water-level readings in the network of observation wells is of utmost importance for future reference.

Geologic data have been compiled to determine the position of the underlying bedrock and thus to determine the thickness and lithology of the alluvium.

In the uplands the collection of basic data for evaluation of groundand surface-water studies has been less intensive than that for the Ohio River and its alluvial deposits. Data on ground vater are included in a work by MacCary (1956) and in the annual series of U.S. Geological Survey water-supply paper's entitled "Surface water supply of the United States" (see list of references, p. C34).

The data show that yields from wells and springs and the flow of streams are subject to seasonal fluctuations; consequently, their watersupply yield is limited. The water resources of the upland area warrant further studies because the data collected to date (1962) are insufficient for a proper evaluation of the area's potential.

\section{APPLICABILITY OF EXISTING DATA FOR MANAGEMENT PURPOSES}

Effective management of available water resources in the T_ouisville area requires that data be adequately applied to answer pertinent questions regarding the potential supply and the effects of water development.

Data collected for the Ohio River at Louisville are used to plot curves that show flow data such as the recurrence interval for flows of known magnitude. To the water manager, the recurrence of low flows would be important with regard to the probable deterioration of chemical and bacteriological quality and increased temperature. The recurrence interval for floods of a specific stage height would de- 
termine the type of installation for setting and protecting pumping and other equipment at the river.

Data collected throughout the area of the alluvial deposits have been used to show the potential supply and the effects of water development in specific areas. Several examples of the use of the data are as follows:

1. An investigation to determine the quantity and quality of water available in northeastern Louisville was made during the period 1945-47. Analyses of data collected during this period showed that $280 \mathrm{mgd}$ of water of suitable quality for domestic and industrial uses could be induced from a 6.4-mile reach of the Ohio River northeast of Louisville (Rorabaugh 1956b).

2. An appraisal of the available ground-water supply southwest of Louisville during the period 1944-46 is described by Rorabaugh (1946a). He estimated the storage to be about 1.5 billion gallons per foot below the water table; infiltration from rainfall on the area, about $11 \mathrm{mgd}$; and flow into the deposit of glacial sand and gravel from the east, about $1 \mathrm{mgd}$. Natural discharge to the river in the area was about 800,000 gpd per mile along the rivar.

3. Periodic water-level measurements have been used to compile the water-level contour maps which show the cones of depressions in the four subareas (pl. 3). Heavy pumping by industry had lowered the water level as much as 60 feet in the south distillery area by 1944 , and 65 feet in the downtown subarea by 1955 . In both areas the water levels were only about 10 feet above the underlying bedrock at the given drawdowns. In the Rubbertown subaren, record lows were observed in 1945. Water levels recovered through 1948, but increased pumpage has again introduced a downward trend, and in the west-central subarea water levels declined to vithin 10 to 15 feet of the underlying bedrock in 1948 .

In the upland area of the county the limitations of ground water in limestone and of the water in streams as a major source of supply have been recognized from the initial water studies. Tro water manager can interpret the data in terms of the local situation and choose between the alternatives of installing individual water supplies for homes or developments, impounding a nearby st:eam. or bringing in water from outside the area.

\section{FLOODING}

\section{CURRENT CONDITIONS}

The great 1937 flood on the Ohio River inundated large parts of the city and adjacent areas and caused property damage of $\$ 57$ mil- 
lion in the Louisville area, according to the U.S. Army Corps of Engineers. Eight years later, in 1945, the second highest flood of record caused property damage estimated at $\$ 4$ million. Subsequent planning by many agencies resulted in the construction-completed in 1953 by the Corps of Engineers at a cost of about $\$ 29$ millionof floodwalls, levees, and pumping stations to protect the city (pl. 3).

In recent years many flood-control dams and reservoirs have been constructed on tributary streams upstream from Louisville in the Ohio River basin. These control structures will have an effect in reducing flood heights at Louisville by delaying part of the floodwaters which normally would contribute to floods at Louisville. These structures in conjunction with the floodwall-levee system at Louisville have largely eliminated the damage caused by flooding of the Ohio River.

Most of the damage from flooding in Jefferson County in recent years can be attributed to flash floods on the tributary streams, notably on Beargrass, Pond, Fern, and Mill Creeks. Generally, average floods on the tributary streams are not troublesome. In extremely high floods, however, poor runoff conditions cause the flocding of homes in wide, flat overflow areas. In particular, this occurs in the upper reaches of Beargrass and Pond Creeks which extend into the suburban residental parts of Louisville. Most of the Beargrass Creek basin drains inside the Louisville floodwall-levee system, and downstream flooding is controlled by the Beargrass Creek pumfing station. In the lower reaches of Pond Creek, backwater frcm Ohio River floods contributes to the flooding of residential areas.

Some flooding occurs in the basin of Floyds Fork, which drains most of the east half of the county, but the basin is sparsel-r settled and floods mainly affect the bottom farmlands.

\section{AVAILABLE HYDROLOGIC DATA AND ADEQUACY}

Flow records available for the Ohio River at and upstreem from Louisville and for the larger tributary streams in Jefferson County are adequate for most needs. There is a continuous record of flood stages on the Ohio River at Louisville for almost 100 years, and continuous daily flow records have been obtained at Louisville since 1928. Continuous flow records have been obtained for Middle and South Fork Beargrass Creek, Pond Creek, and Floyds Fork since August 1944. Flood-stage and floodflow frequency curves have been developed from these records and are available for water development planning purposes and for design of control and use structures.

A flood-inundation map is available for the $1937 \mathrm{flood}_{\text {, but similar }}$ maps are not available or are incomplete for the later majcr floods. Such maps are essential to fix precise floodwater elevations and limits. 
Modern topographic maps are available for the entire area but have been rapidly outdated by construction activities.

\section{APPLICABILITY OF EXISTING DATA FOR MANAGEMENT PURPOSES}

Design of control structures and many planning and zoring activities related to flooding are based on the availability of basic hydrologic records. Flood-frequency curves provide an evaluation of the average frequency of recurrence which may be expected for floods of various magnitudes on the Ohio River at Louisville. Bas?d on this evaluation, a flood equaling or exceeding flood stage-crest elevation, 431 feet msl (mean sea level); peak discharge, 500,000 cfs-may be expected to occur every 1 or 2 years, on the average.

On this same basis a verage recurrence frequencies for floods of other magnitudes on the Ohio River at Louisville are as follows:

\begin{tabular}{ccc}
$\begin{array}{c}\text { Recurrence } \\
\text { interval } \\
(\text { years })\end{array}$ & $\begin{array}{c}\text { Crest elevation } \\
\text { (ft above msl) }\end{array}$ & $\begin{array}{c}\text { Peak } \\
\text { discharge } \\
(\text { (ffs) }\end{array}$ \\
\hline $\mathbf{2 0}$ & 445.5 & 720,000 \\
& 450 & 820,000
\end{tabular}

Most floods and all high floods on the Ohio River at Louisville have occurred during the 4-month period January through April. Major floods rise and recede at a relatively slow rate, usually remaining at or near the crest for several days. For example, in the record 1.937 flood, the stage of the Ohio River at Louisville was within a foot of the crest for 3 days and within 5 feet of the crest for 9 days.

Damage from flooding on tributary streams in Jefferson County could be relieved further by small flood-control structures and reservoirs in the upper reaches of the streams. The water thus stored could be used for irrigation and stock supplies and for recreation if the quality is satisfactory. The planning for these structures should be done in conjunction with an adequate program of planning and zoning to insure that residential building does not take place in floodwaterretention areas. To this end flood-inundation maps should be prepared for all tributary basins to indicate areas where waters will pond during and after floods.

Collection and analysis of continuous-flow records should be continued to monitor changes brought about by flood-control structures and urbanization. The addition of hundreds of acres of streets, drives, sidewalks, and roofs will increase the speed and magnitude of runoff, and existing frequency curves will need to be adjusted accordingly.

Flood-inundation maps should be updated as rapidly as construction progresses and land contour's are changed. These maps should be published and made available to all interested users. 


\section{DROUGHTS}

Periods of unusual dryness occur at frequent intervals in the Louisville area, but the periods do not follow a regular sequence and extreme conditions do not prevail for long periods of time. Serious droughts occurred in the summer of 1930 and in the success've summers of 1952-54. From the standpoint of the area's water resources, the seriousness of a drought is measured by its effect on water supply, power generation, and waste disposal. The usual effects are Jowering of streamflow and ground-water levels.

\section{CURRENT CONDITIONS}

Droughts of the magnitude experienced in the Louisville area have little effect on municipal and industrial water supplies and on power generation. Because of the large volume of water flowing in or stored in the major sources of these supplies (the Ohio River and the deposits of alluvial sand and gravel), prolonged drought rarely lowers the supply to a point that approaches the demand.

Local water problems, however, are caused by droughts. Water shortages become acute in the uplands of the eastern and southeastern parts of Jefferson County where public water supplies are not available. Flow in most of the streams ceases and many shallow wells, springs, cisterns, and ponds become dry. Water for domestic and stock uses must be hauled into the area affected. Lack of streamflow for dilution of sewage and industrial waste creates a health hazard in some localities. Growth of algae during these periods imparts an unpleasant taste that is difficult to eliminate from the water.

\section{AVAILABLE HYDROLOGIC DATA AND ADEQUACY}

Flow records are available for the Ohio River and for the larger tributary streams in Jefferson County and are adequate to indicate the seriousness of drought. Drought-frequency curves showing the recurrence expectancy of minimum flows have been developed from these records and are adequate for use in planning for reservoir-storage facilities for emergency supply and for dilution of waste. A vailable ground-water information includes continuous and periodic waterlevel measurements in sand-and-gravel aquifers and periocic measurements in bedrock aquifers. Quantitative estimates of ground water in storage are available for most sand-and-gravel aquifers but are not available for bedrock aquifers. The available data are adequate to indicate the effect of droughts on sand-and-gravel aquifers and to predict problem areas. Additional information is needed for bedrock aquifers.

$791-6030-66-3$ 


\section{APPLICABILITY OF EXISTING DATA FOR MANAGEMENT PURPOSES}

Flow data indicate that droughts have little effect on the adequacy of the Ohio River to supply water needs at current use rates and at projected use rates for the near future. The minimum daily flow of the Ohio River of $2,100 \mathrm{cfs}$ recorded in 1930 during the hejght of the most serious drought of record is shown to be about 11 times greater than the maximum daily pumpage to date (1962) by the Louisville Water Company. Thus, water managers can plan for greater withdrawals from the Ohio River without fear of depleting the supply. In contrast, the flow of most tributary streams in the uplands of Jefferson County recedes to a very low quantity in late summer and fall, and the streams sometimes go dry for periods of a few days to a few weeks. The use of these streams as sources of perennial water supply or for dilution of waste would require that storage facilities be provided. The drought-frequency curves can be used to determine the amount of storage required to maintain specific outflow rates for a specific period of time.

Additional ground water is available for development from the sand-and-gravel aquifer in the flood plain. The potential supply available from the deposit of sand and gravel without depletion of storage is estimated to be about $370 \mathrm{mgd}$ (Bell, 1962). Thus, the estimated average withdrawal of about $40 \mathrm{mgd}$ in 1962 is only 11 percent of the available supply. Drought decreases the smount of ground water in storage in the sand-and-gravel deposit, but the longterm record of water-level measurements shows that thero is little need for concern during the average drought. A more seriouः drought, such as the droughts experienced in the three successive summers of 1952-54, caused water levels in two centers of pumping to decline to levels that were only 10 feet above the surface of the bedrock. The amount of the decline that may have been due to increased pumping is difficult to assess, however.

The available records indicate that water levels in the bedrock aquifers of the uplands are more affected by drought than are those in the flood plain. Springs and the shallower wells often go dry during average droughts. The coverage of periodic water-level measurements is not now adequate to indicate minimum levels for all parts of the upland, but the data can be used to predict minimum levels, which can be used to specify the desired depth of drilling of wells in bedrock. Sufficient ground water is available to sustain the yield of many more wells in the area, provided that the wells are drilled to the proper depth. 


\section{CHEMICAL QUALITY AND POLLUTION}

\section{CURRENT CONDITIONS}

Through the efforts of ORSANCO and Federal, State, and local governments, almost a billion dollars has been invested by cities and towns in the Ohio Valley for pollution-abatement facilities. Sewagetreatment plants serving 90 percent of the sewer-using population of the Ohio Valley are in operation or under construction $(1962) ; 97$ percent of the population on the main stem of the Ohio River is thus served. In addition, ORSANCO minimum requirements for waste control are being met by 85 percent of the industrial establishments. As a result the quality of the water in the Ohio River at Louisville has improved steadily in the 14 years since ORSANCO was formed. Periodic monitoring of the quality of the Ohio River is done by the Louisville Water Company in cooperation with ORSANCO.

The quality of the water in the tributary streams in Jefferson County is not monitored on a systematic basis but is checled periodically by State and local health agencies. The quality has been improved by the extension of sewage systems and the installations of sewage-treatment facilities for suburban developments. The chemical character of the water in Pond Creek is altered by industrial wastes discharged into it, and thus its quality is the least acceptable of all the tributary streams.

The chemical quality of ground water in the area is suitable for domestic and some industrial uses except in a few local are's where the water is contaminated by outside sources. The ground water is generally hard; water from alluvium contains a high concentration of iron. In addition, a high concentration of sulfate is present in alluvial ground water in the north-central part of the city. The prosence of these constituents requires that the water be treated for some industrial uses. The water from alluvium is sampled periodically by the Geological Survey at 12 wells, and local industries collect samples at additional wells.

\section{A VAILABLE HYDROLOGIC DATA AND APPLICABILITY FOR MANAGEMENT PURPOSES}

Data on the quality of the Ohio River water are available through the monitoring system of ORSANCO and the Louisville Water Company and are probably adequate for most management decisions. The type and cost of treatment for various requirements can be estimated from the accumulated data, and changes in treatment needed for changing river quality are forecast from the monitoring system. The river quality should change little in the reach through Jefferson 
County, provided that the quality of the water entering the main stream from the several tributary streams is controlled.

Some analyses of the water from the smaller streams in the county are available and are useful for planning and for developing supplies. The existing data are probably adequate to show the suitability of the water for specific uses. However, the usefulness of the data could be enhanced by periodic monitoring of the streams downstraam from known or potential sources of pollution. Changes in quality with time would be indicated and would serve as a guide for future treatment.

Sampling and analysis of ground water in the alluvial area of Louisville is done annually by the Geological Survey. There is no periodic sampling from wells in the bedrock of the uplands but spot analyses are available for this area. The existing data on cuality of ground water are sufficient to show the suitability of the water for specific uses. They are also adequate to show the location and extent of the concentrations of mineral constituents and the physical properties of the ground water that are objectionable. Periodic sampling near known centers of contamination should be continued to indicate changes in quality.

\section{DRAINAGE}

Lack of adequate surface drainage is a pressing probler when it becomes detrimental to human health and well-being and affects the economy of a community. Areas of poor drainage that are rubject to waterlogging affect the operation of individual household sewagedisposal systems and become a health hazard. Heavy rains s metimes overload the smaller drainageways, causing local floods. A problem also exists during long periods of little or no runoff when drainage channels become overgrown with weeds or serve as breeding grounds for mosquitoes.

\section{CURRENT CONDITIONS}

The low-lying areas in the southern and southwestern parts of Louisville and Jefferson County, extending from Shively northeast to the St. Matthews area, part of which formerly was known as the "Wet Woods," have little topographic relief and are underlain by silt and clay or impermeable shale at shallow depth. Downward seepage of water is restricted, and during rainy seasons water accumulates in numerous small depressions. Natural drainage is poor and water is carried off primarily in manmade ditches, some of which are too shallow or narrow to drain a way the water as fast as it accrmulates. 
Ponding and saturation of the soil on top of the shale often rasult in flooded basements and in malfunction of septic tanks and Jeaching fields. The drainage problem is aggravated in summer months because the ditches become clogged with weeds and refuse that impede the flow of water.

AVALLABLE HYDROLOGIC DATA AND APPLICABILIT'

Problems of inadequate drainage were not within the scops of the Survey's water-resource investigations in the Louisville area. The Louisville Metropolitan Sewer District has investigated and rade recommendations on the need for storm sewers, drainage ditches, culverts, and concrete-lined channels within the city of Louisville and in southwestern Jefferson County. There is a need for a similar study of the whole of Jefferson County outside the city. Many of the local problems are related to impermeable soil and rock material that limit subsurface drainage. Some of the problems in the past he.ve been lessened by restrictions on the installation of new septic tanks and leaching fields in saturated areas and by the gradual extension of storm and sanitary sewers to serve the problem areas.

Data used in solving drainage problems include data on megnitude of runoff with time from the tributary basins, geologic and subsurface maps, and information on the depth to the water table.

\section{CONCLUSIONS}

The abundance of water in the Ohio River and in the alluvium beneath the flood plain practically precludes a serious shortage of water in the Louisville area. The minimum flow of record of the Ohio River at Louisville of $2,100 \mathrm{cfs}(1,360 \mathrm{mgd})$ plus the extimated potential available ground water of $370 \mathrm{mgd}$ far exceeds the $211 \mathrm{mgd}$ of water withdrawn for public and industrial uses in 1962.

The Ohio River supplies water for all uses in the area and is the source of the municipal supply for Louisville. Ground water in the alluvium is utilized for industrial cooling and, in the southwestern part of the area, is also a source of municipal supply. Limestone underlying the alluvium in the west-central part of Louisville is a secondary source of water for industrial cooling. Bedroct in the uplands yields water to some wells and springs for domestic and stock uses.

Natural waters in the area are generally of the calcium bic rrbonate or calcium magnesium bicarbonate type and contain varying amounts of sulfate. Ground water is very hard and commonly contains iron in excess of $1 \mathrm{ppm}$. 
Water problems of the area are chiefly those of managgment and are associated with floods, drought, drainage, and the distribution and quality of available supplies.

Much information on water resources, contained in reports resulting from water investigations during the past two decades, has been helpful to water users for planning and developing supplies. Although the data are applicable in similar situations, up-to-date water information will be needed to resolve problems created by demards in the future.

\section{SELECTED REFERENCES}

American Water Works Association Journal, 1945, Conservation of ground water in the Louisville area, Kentucky: Am. Water Works Assoc. Jour., v. 37, no. 6, p. 543-560.

Bell, E. A., 1962, The ground-water situation in the Louisville area. Kentucky, 1945-61: Kentucky Geol. Survey, ser. 10, Inf. Circ. 10, 24 p.

Bell, E. A., Kellogg, R. W., and Kulp, W. K., 1963, Progress report on the groundwater resources of the Louisville area, Kentucky, 1949-55: U.S. Geol. Survey Water-Supply Paper 1579, 49 p.

Butts, Charles, 1915a, Geological map of Jefferson County, Kentucky : Frankfort, Ky., Kentucky Geol. Survey.

1915b, Geology and mineral resources of Jefferson County, Kentucky: Kentucky Geol. Survey, ser. 4, v. 3, 270 p.

Care, W. M., 1939, Ground water-well report: Louisville, Ky., Comm. cf Sewerage of Louisville, 24 p., 9 illus.

Commissioners of Sewerage of Louisville, 1942, Final report of the Conmissioners of Sewerage of Louisville, 1919-42: Louisville, Ky., p. 369-387, 6 figs.

Diehl, R. B., 1913, The diminishing supply and conservation of the underground water supply of Louisville, Kentucky: Louisville, Ky., Diehl Pump and Supply Co. open-file rept., 20 p., 2 illus.

Grover, N. C., 1938, Floods of Ohio and Mississippi Rivers, Januar:-February 1937, with a section on the flood deposits of the Ohio River, January-February 1937, by G. R. Mansfield: U.S. Geol. Survey Water-Supply Paper 838, p. 693-736.

Guyton, W. F., 1944, Artificial recharge of ground-water reservoir with water from city's surface supply at Louisville, Ky.: U.S. Geol. Survey open-file rept. prepared in coop. with Kentucky Dept. Mines Minerals Geol. Div., 6 p., 1 fig.

1945, Depleted wells at Louisville recharged with city water: Water Works Eng., v. 98, no. 1, p. 18-20.

1946, Artificial recharge of glacial sand and gravel with filtered river water at Louisville, Ky. : Econ. Geology, v. 41, no. 6, p. 644-658.

Guyton, W. F., Stuart, W. T., and Maxey, G. B., 1944, Progress report on the ground-water resources of the Louisville area, Kentucky: U.S. Geol. Survey open-file rept. prepared in coop. with Kentucky Dept. Mines Minerals Geol. Div. and city of Louisville, 20 p., 12 figs.

Guyton, W. F., and Sublett, H. E., 1944, Conservation of ground water in the Louisville area, Kentucky: U.S. Geol. Survey open-file rept. prepared in coop. with Kentucky Dept. Mines Minerals Geol. Div., 4 p., 9 illus. 
Hamilton, D. K., 1944, Ground water in the bedrock beneath the glacial outwash in the Louisville area, Kentucky : U.S. Geol. Survey open-file rept. prepared in coop. with Kentucky Dept. Mines Minerals Geol. Div., 22 p. incl. maps.

Kazmann, R. G., 1948, River infiltration as a source of ground-water supply : Am. Soc. Civil Engineers Trans., v. 113, p. 404-420.

Louisville Water Company, Annual reports: Louisville, $\mathbf{K y}$.

MacCary, L. M., 1955, Map of the Louisville area, Kentucky, showing contours on the bedrock surface: U.S. Geol. Survey Hydrol. Inv. Atlas HA-5, 1 sheet.

- 1956, Availability of ground water for domestic use in Jefferson County, Kentucky : U.S. Geol. Survey Hydrol. Inv. Atlas HA-8, 5 p.

McFarlan, A. C., 1943, Geology of Kentucky : Lexington, Ky., Univ. Kentucky, $531 \mathrm{p}$.

Maier, F. J., 1950, Fluoridation of public water supplies: Am. Water Works Assoc. Jour., v. 42, pt. 1, p. 1120-1132.

Maxcy, K. F., 1950, Report on the relation of nitrate concentration in wall waters to the occurrence of methemoglobinemia: Natl. Research Courcil, Bull. Sanitary En., app. D., p. 265.

Ohio River Valley Water Sanitation Commission, 1950, Pollution patte"ns in the Ohio River: Cincinnati, Ohio, $30 \mathrm{p}$.

Price, W. E., Jr., 1964a, Geology and hydrology of alluvial deposits along the Ohio River between Prospect and southwestern Louisville, Kenturky : U.S. Geol. Survey Hydrol. Inv. Atlas HA-130, 2 sheets.

- 1964b, Geology and hydrology of alluvial deposits along the Ohio River between southwestern Louisville and West Point, Kentucky: U.S. Geol. Survey Hydrol. Inv. Atlas HA-111, 2 sheets.

Rorabaugh, M. I., 1946a, Ground-water resources of the southwestern part of the Louisville area, Kentucky: U.S. Geol. Survey open-file rept. prepared in coop. with Rubber Reserve Co., city of Louisville, and Jefferson County. $39 \mathrm{p}$.

1946b, Inventory of water wells, Louisville area, Kentucky: U.S. Geol. Survey open-file rept. prepared in coop. with city of Louisville and Jefferson County, 35 p., 1 fig.

1949a, Investigation discloses large ground-water supply: The Louisville Engineer and Scientist, r. 5, no. 4, p. 1-10.

$1949 \mathrm{~b}$, Progress report on the ground-water resources of the Louisville area, Kentucky, 1945-49: U.S. Geol. Survey open-file rept. prepared in coop. with city of Louisville and Jefferson County, 64 p.

1951, Stream-bed percolation in development of water supplies : Brussels, Internat. Assoc. Hydrology, p. 165-174.

1956a, Prediction of ground-water levels on basis of rainfall anc temperature correlations: Am. Geophys. Union Trans., v. 37, no. 4, p 436-441. 1956b, Ground water in northeastern Louisville, Kentucky: U.S. Geol. Survey Water-Supply Paper 1360-B, p. 101-169.

Rorabaugh, M. I., Schrader, F. F., and Laird, L. B., 1953, Water resources of the Louisville area, Kentucky and Indiana: U.S. Geol. Survey Circ. 276, 49 p., 2 pls.

Schrader, F. F., 1915, Water: Univ. Kentucky, Bur. School Service B`1l., v. 18, no. 2, p. 45-122.

Shoecraft, E. C., Drury, W. R., and McNamee, R. L., 1944, Report on water resources for the Underground Water Users Association, Louisville, I.y. : Openfile rept., 120 p., 20 illus. 
Spicer, H. C., 1946, Electrical resistivity studies of the depth to becrock in the Louisville area, Kentucky: U.S. Geol. Survey open-file rept., 21 p., 2 figs.

Stuart, W. T., 1944, Conservation of ground water, including artificial recharge, by two companies in the Louisville area, Kentucky: U.S. Gool. Survey open-file rept. prepared in coop. with Kentucky Dept. Mines Minerals Geol. Div., $10 \mathrm{p}$.

Sublett, H. E., 1945, Chemical quality of ground water in the Lou'sville area, Kentucky : U.S. Geol. Survey open-file rept. prepared in coop. with Kentucky Dept. Mines Minerals Geol. Div., 8 p., 4 figs.

U.S. Geological Survey, 1944, Chemical analyses of water from wells in the Louisville area, Kentucky: U.S. Geol. Survey open-file rept. prepared in coop. with Kentucky Dept. Mines Minerals Geol. Div., 6 p.

1945, Drillers' logs of wells and test borings in the Louisville area, Kentucky : U.S. Geol. Survey open-file rept. prepared in coop. with Kentucky Dept. Mines Minerals Geol. Div., 70 p., 1 map.

issued annually through 1960 and on a 5-year basis thereafter. Surfacewater supply of the United States, Part 3-A, Ohio River besin except Cumberland and Tennessee River basins: U.S. Geol. Survey witer-supply papers.

issued annually through 1955, on a 3-year basis for 1956-58, and on a 5-year basis thereafter, Water levels and artesian pressure in observation wells in the United States, Part 2, Southeastern States: U.S. Geol. Survey watersupply papers.

U.S. Public Health Service, 1962, Drinking water standards : U.S. Public Health Service Pub. no. 956, $61 \mathrm{p}$.

Walker, W. H., 1957, An aquifer test in the southwestern part of the Louisville area, Kentucky : U.S. Geol. Survey open-file rept., $41 \mathrm{p}$.

Wenger, H. V., 1943, Report on the ground-water supply, Louisville, Kentucky: [U.S.] War Production Board open-file rept., 12 p.

Whitesides, D. V., and Nichols, Edith S., 1961, Water levels in observation wells in Jefferson County, Kentucky, 1935 through 1960: Kentucky Geol. Survey, ser. 10, Inf. Circ. 6, 75 p. 
MISSISSIPPIAN PERIOD

Sage Series
Holtsclaw Sandston

DEVONIAN PERIOD

Jeffersonville Limestone

SILURIAN PERIOD

Louisville Limeston
Waldron Shale

Silurian and Ordovician formations undifferentiated
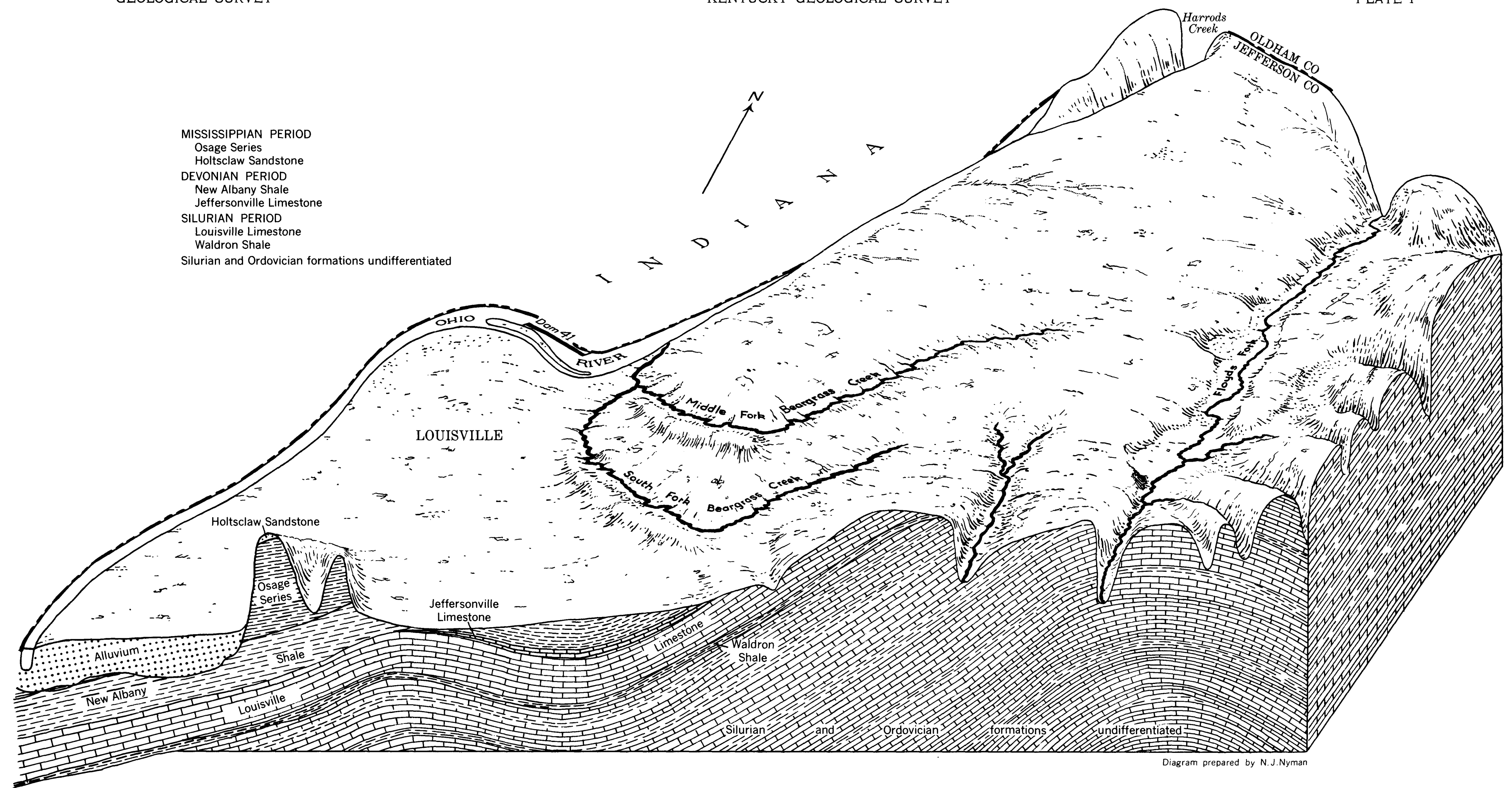

BLOCK DIAGRAM SHOWING PHYSIOGRAPHIC AND GEOLOGIC FEATURES THAT CONTROL THE MOVEMENT OF NATURAL WATERS IN THE LOUISVILLE AREA, KENTUCKY 


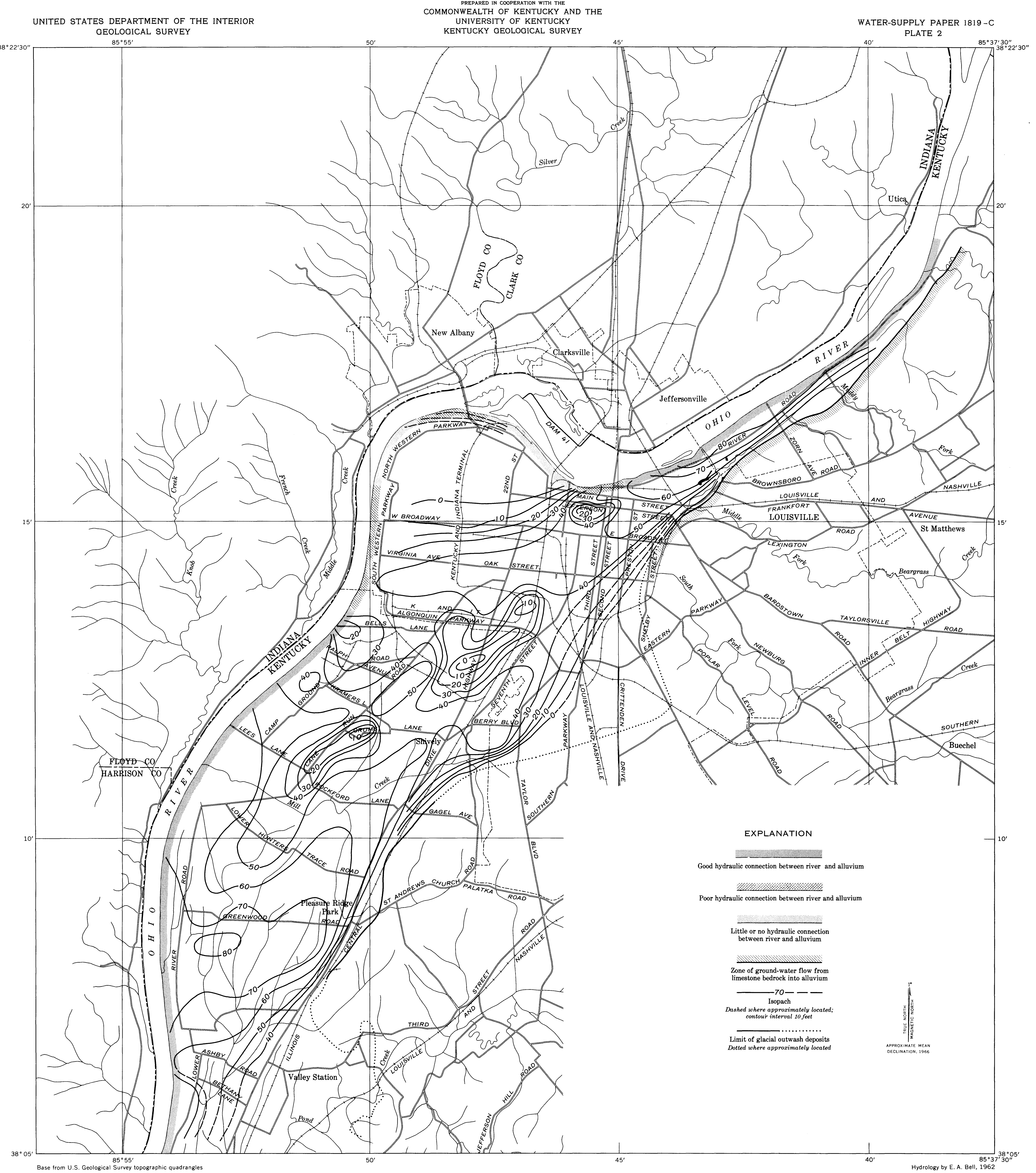

MAP SHOWING THICKNESS OF SATURATED SAND AND GRAVEL BENEATH THE FLOOD PLAIN OF THE OHIO RIVER IN THE LOUISVILLE AREA, KENTUCKY, DECEMBER 1962, AND DEGREE OF HYDRAULIC CONNECTION BETWEEN THE RIVER AND AQUIFER 




MAP SHOWING WATER-LEVEL CONTOURS BENEATH THE FLOOD PLAIN OF THE OHIO RIVER IN THE LOUISVILLE AREA, KENTUCKY, DECEMBER 1962 


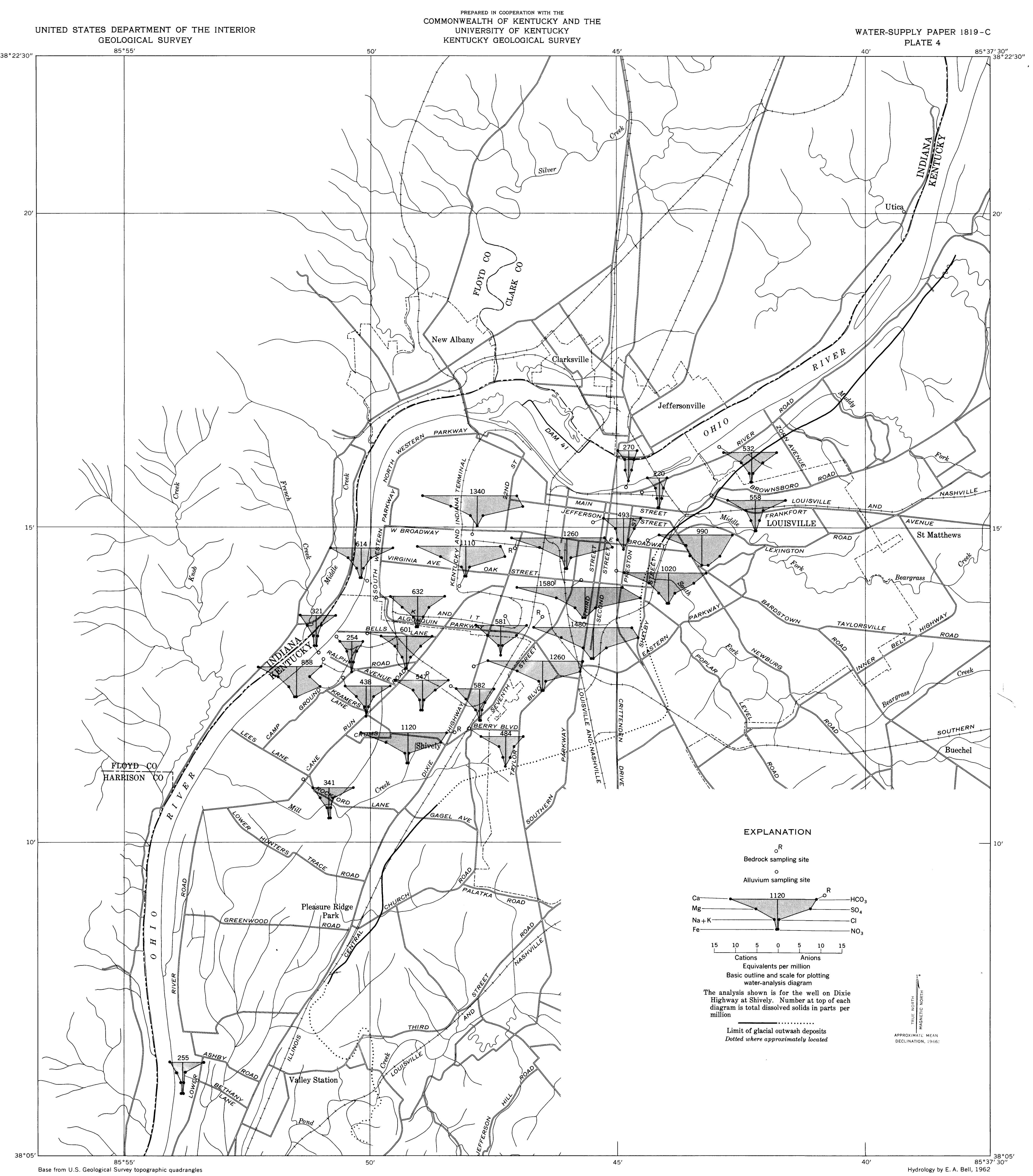

MAP SHOWING THE CHEMICAL CHARACTER OF GROUND WATER BENEATH THE FLOOD PLAIN OF THE OHIO RIVER IN THE LOUISVILLE AREA, KENTUCKY

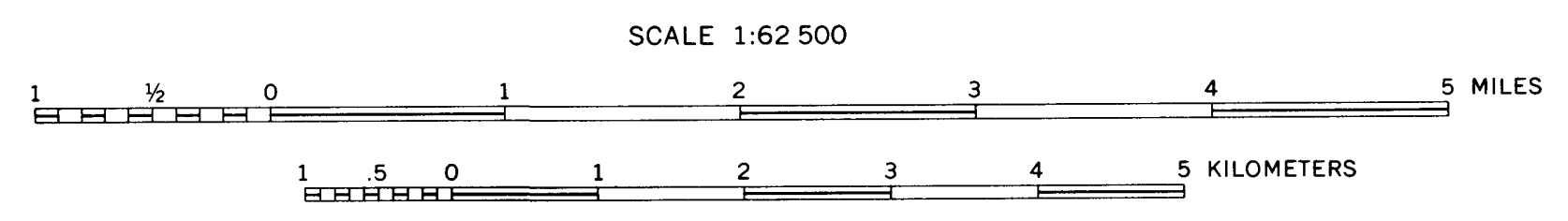




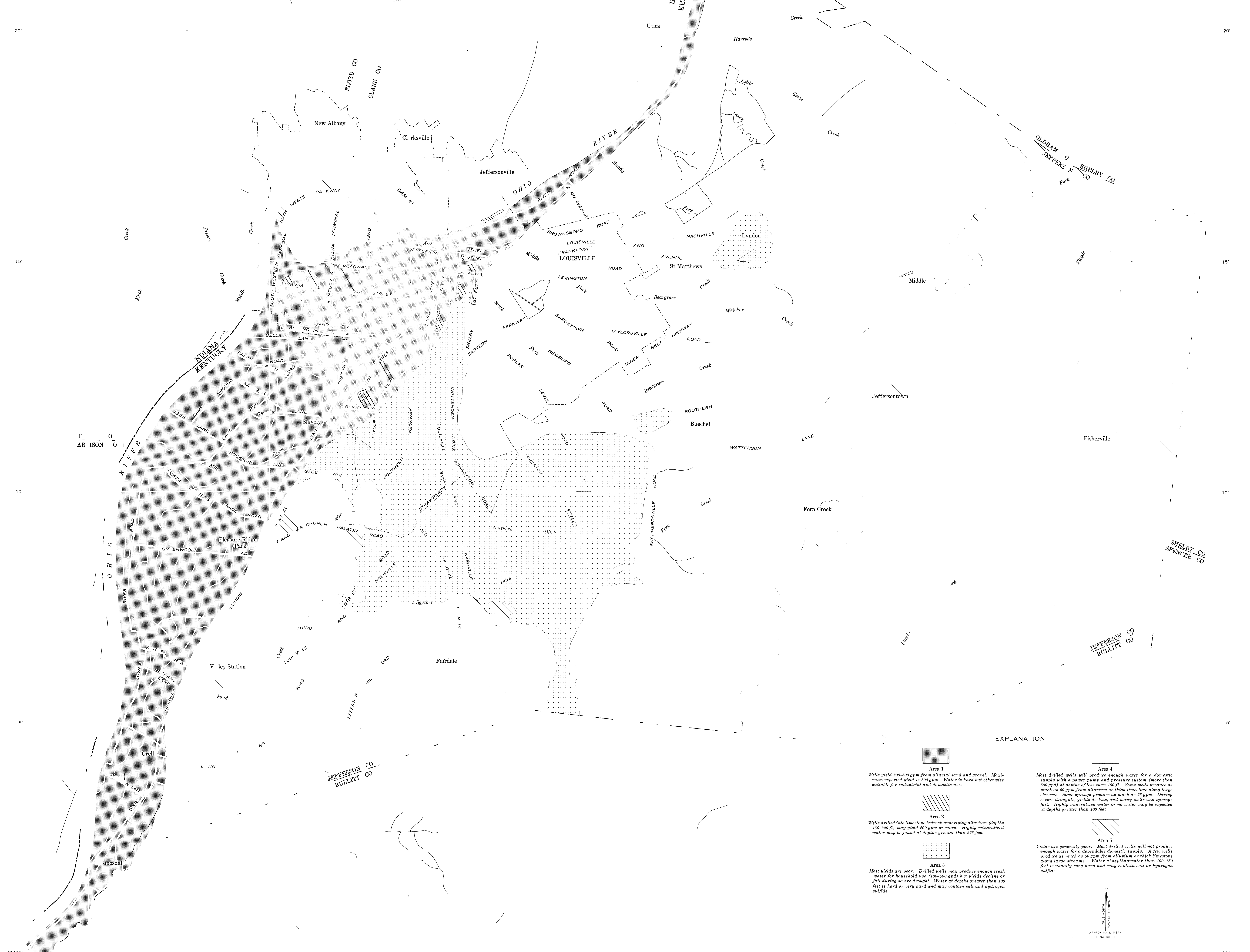



: DOWNTOWN SUBAREA

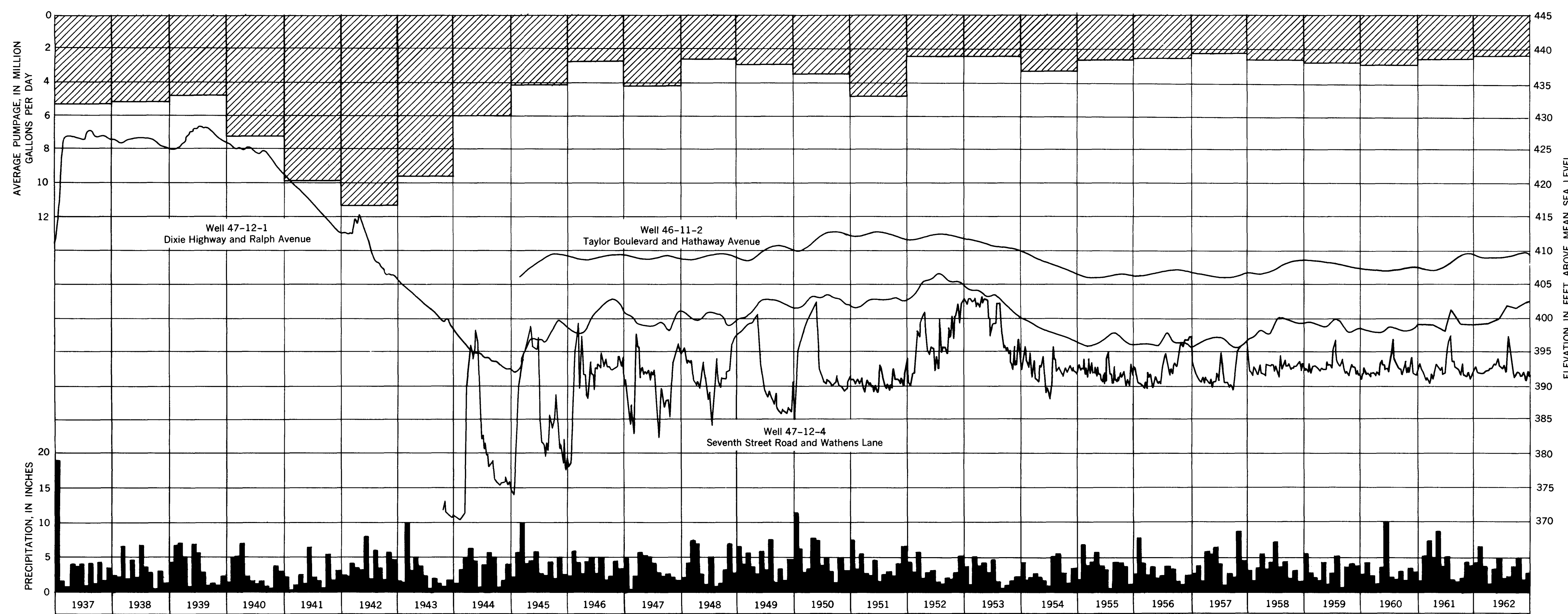
SOUTH DISTILLERY SUBAREA

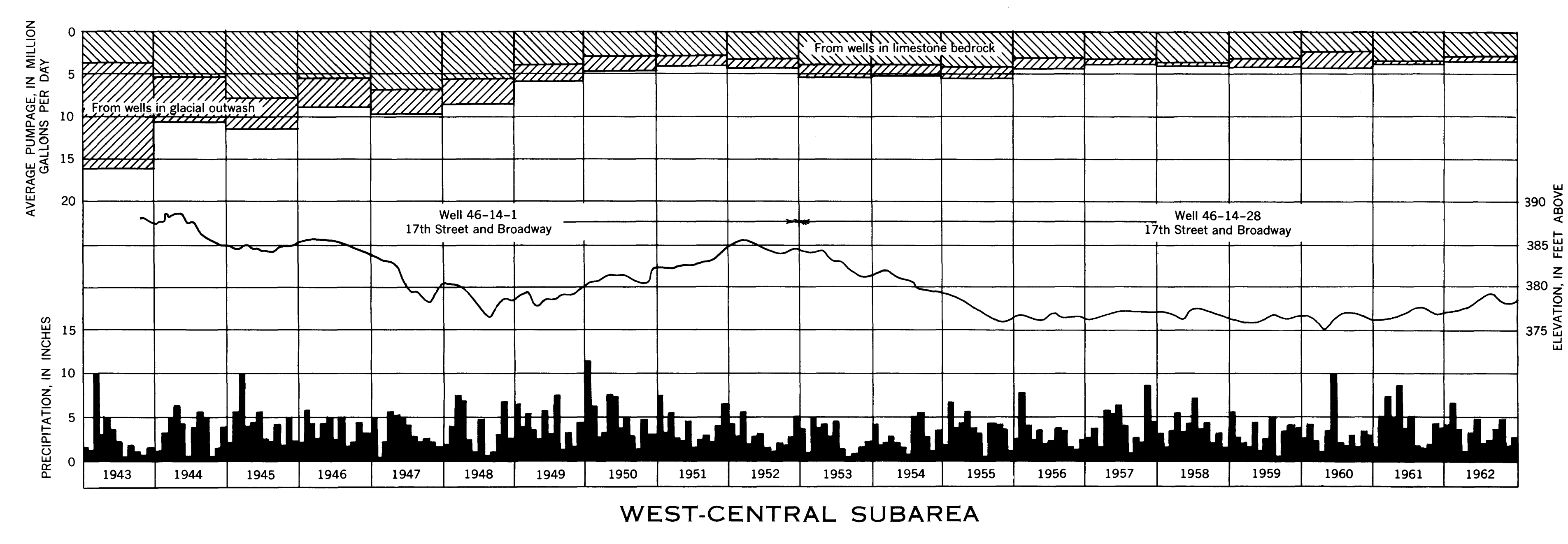

WEST CENTRAL SUDAREA

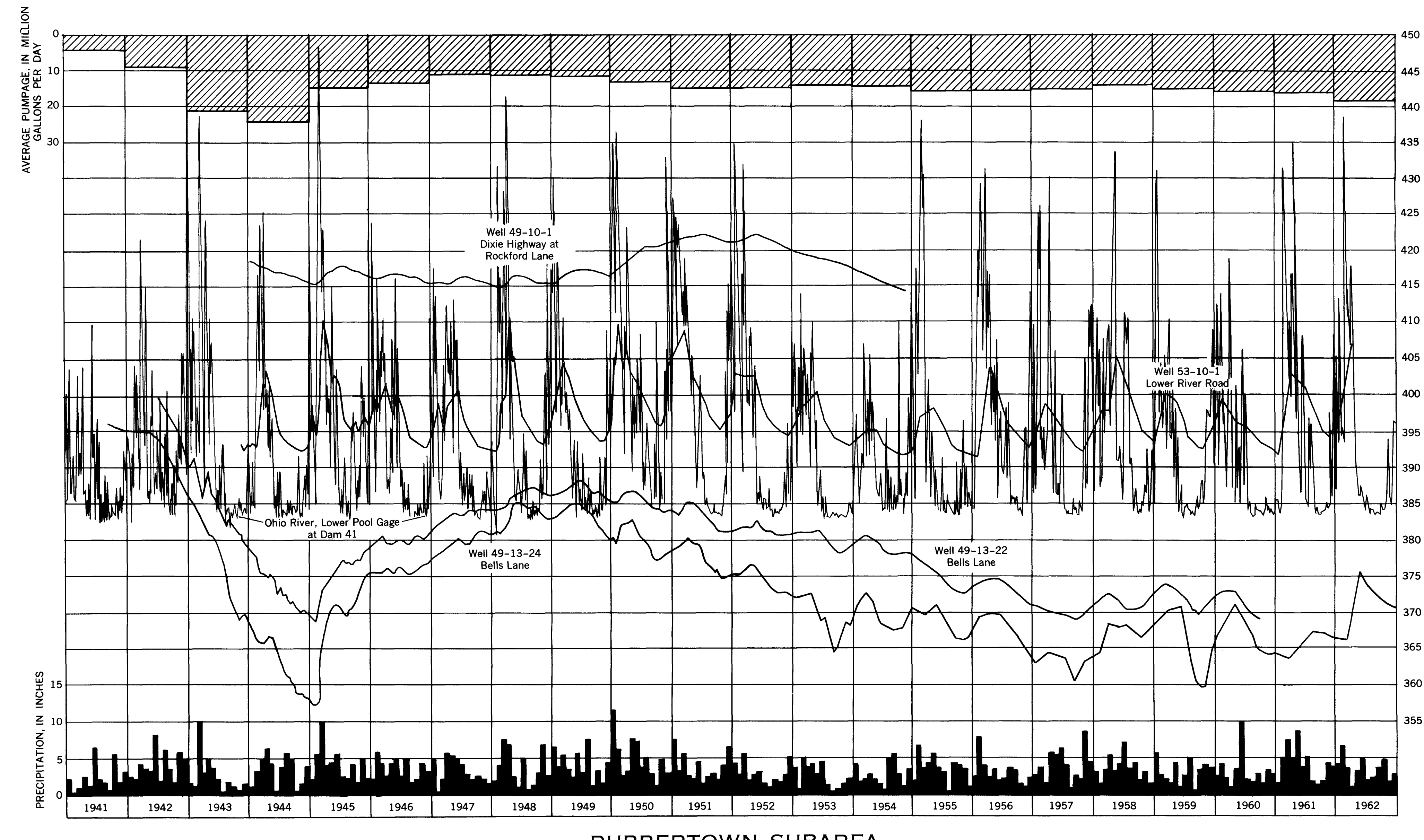

RUBBERTOWN SUBAREA 